\title{
Characterizing the physical properties of rocks from the Paleozoic to Permo-Triassic transition in the Upper Rhine Graben
}

\author{
Alexandra R. L. Kushnir ${ }^{*}$, Michael J. Heap ${ }^{1}$, Patrick Baud ${ }^{1}$, H. Albert Gilg², Thierry Reuschlé ${ }^{1}$, Catherine Lerouge ${ }^{3}$, \\ Chrystel Dezayes ${ }^{3}$ and Philippe Duringer ${ }^{4}$
}

*Correspondence:

alexandra.kushnir@gmail.

com

${ }^{1}$ Géophysique

Expérimentale, Institut de Physique du Globe de Strasbourg (UMR 7516, CNRS, Université de Strasbourg/ EOST), Strasbourg, France Full list of author information is available at the end of the article

\begin{abstract}
Geothermal energy exploitation in the Upper Rhine Graben currently targets hightemperature anomalies in the crystalline Paleozoic basement at depths up to $5 \mathrm{~km}$. However, at certain locations (e.g. Rittershoffen, France), geothermal installations are actively targeting resources at shallower depths where the Paleozoic granite transitions into the overlying Permo-Triassic sandstones. We here investigate the variation in physical properties-including porosity, P-wave velocity, permeability, uniaxial compressive strength, and thermal properties - in rocks that locally extend across the PaleozoicPermo-Triassic boundary in four locations to the west of the Upper Rhine Graben. The lithologies investigated include sandstones, breccia, granites, metagranites, dolomite, and altered and unaltered volcanic rocks and represent the variety of lithologies at this transition. We note that while the porosity, permeability, thermal conductivity, and P-wave velocity of the Permo-Triassic sedimentary cover and Paleozoic crystalline basement rocks are consistent with values determined for rocks from exploratory and production boreholes at Soultz-sous-Forêts (France), the other lithologies (belonging to neither the sedimentary nor basement sequences) are conspicuously lower in porosity and permeability. Further, the attendant strength of these other lithologies could make them relatively unamenable to fracturing, reducing the possibility of fracturecontrolled permeability in these units. Indeed, we conclude that in areas where these low-permeability and high-strength rocks act to cap the crystalline basement, hydrothermal convection may be curtailed and geothermal exploitation may be rendered untenable.
\end{abstract}

Keywords: Permeability, Porosity, Thermal conductivity, UCS, Seismic velocity, Geothermal

\section{Background}

Geothermal energy has emerged as an attractive alternative to fossil fuel resources in part because it represents a carbon-free energy supply that can be exploited regardless of the time of day or year. Of particular interest is the increasing economic viability and technological feasibility of geothermal exploitation in non-volcanic environments. For example, the last 30 years has seen the development of economically viable deep geothermal resources in continental Europe, where electricity and heat are being generated by exploiting the high geothermal gradients extant in intracratonic basins, crystalline

(c) The Author(s) 2018. This article is distributed under the terms of the Creative Commons Attribution 4.0 International License (http://creativecommons.org/licenses/by/4.0/), which permits unrestricted use, distribution, and reproduction in any medium, provided you give appropriate credit to the original author(s) and the source, provide a link to the Creative Commons license, and indicate if changes were made. 
massifs, and continental rifts (e.g. Ungemach and Antics (2010)). Several successful geothermal case studies highlight the viability of geothermal energy generation and/ or direct-use from deep crustal reservoirs where hot (up to $200{ }^{\circ} \mathrm{C}$ ) fluids circulate at depths in excess of $1 \mathrm{~km}$ (Baria et al. 1999; Laplaige et al. 2000; Kappelmeyer et al. 1991; Baujard et al. 2017; Housse 1984; Baumgärtner and Lerch 2013; Hettkamp et al. 2013; Antics and Sanner 2007; Menzel et al. 2000; Mahler and Magtengaard 2005; Lund et al. 2005; Paschen et al. 2003). However, particular barriers to the development of deep geothermal resources in sedimentary basins are the risks of wellbore instabilities (Dusseault 2011; Zeynali 2012) and the high costs associated with deep drilling exploration (York et al. 2009; Proehl 2002; Li et al. 2012). Thus, the physico-chemical characterisation of regional rocks analogous to lithologies that may be in proximity to reservoirs informs the analysis and interpretation of non-invasive geophysical exploration techniques and regional modelling (Reyer and Philipp 2014) and can help mitigate these risks (Khaksar et al. 2009).

To date, there are several active industrial geothermal plants in the Upper Rhine Graben producing electricity, heat, or a cogeneration of the two including the sites of Landau (Hettkamp et al. 2013) and Insheim (Baumgärtner and Lerch 2013) in Germany and Soultz-sous-Forêts (Baria et al. 1999; Kappelmeyer et al. 1991; Gérard et al. 2006) and Rittershoffen (Baujard et al. 2017) in France. The geothermal project near the town of Soultz-sous-Forêts was initiated in 1987 (Gérard and Kappelmeyer 1987) as a scientific pilot plant and is, therefore, the most thoroughly studied geothermal system in the Upper Rhine Graben. There, the Paleozoic granitic basement has been targeted, ultimately exploiting hot (up to $200{ }^{\circ} \mathrm{C}$ ) brines from a depth of $5 \mathrm{~km}$ (Gérard et al. 2006). Recently, however, due to the need for lower temperatures and the high cost of deep drilling, the transition zone between the crystalline Paleozoic basement and the PermoTriassic sedimentary cover has been targeted for geothermal heat exploitation (e.g. Baujard et al. (2017)). Thus, the characterisation of the variability of rocks in this zone is useful to the improvement of our understanding of geothermal reservoirs in deep basins, enabling the technical and economic exploitation of these resources.

Here, we characterise the physical properties (including porosity, permeability, seismic velocity, thermal properties, and uniaxial compressive strength) of rocks from the transition between the Paleozoic crystalline basement and the Permo-Triassic sedimentary cover in the Upper Rhine Graben. We have chosen four locations on the margins of the Upper Rhine Graben where this transition zone outcrops and from which samples could be easily procured. By characterising these rocks, we address the possible variability of the lithological boundaries of the Paleozoic to Permo-Triassic transition at depth throughout the region.

\section{Upper Rhine Graben quarries and sample suite}

We characterise a selection of the main lithologies that may delineate the transition from the Paleozoic crystalline basement to the sedimentary cover within the Upper Rhine Graben by procuring rock samples from four different quarries: Saint Pierre Bois (Alsace, France), Raon l'Etape (Alsace, France), Waldhambach (Baden-Württemberg, 

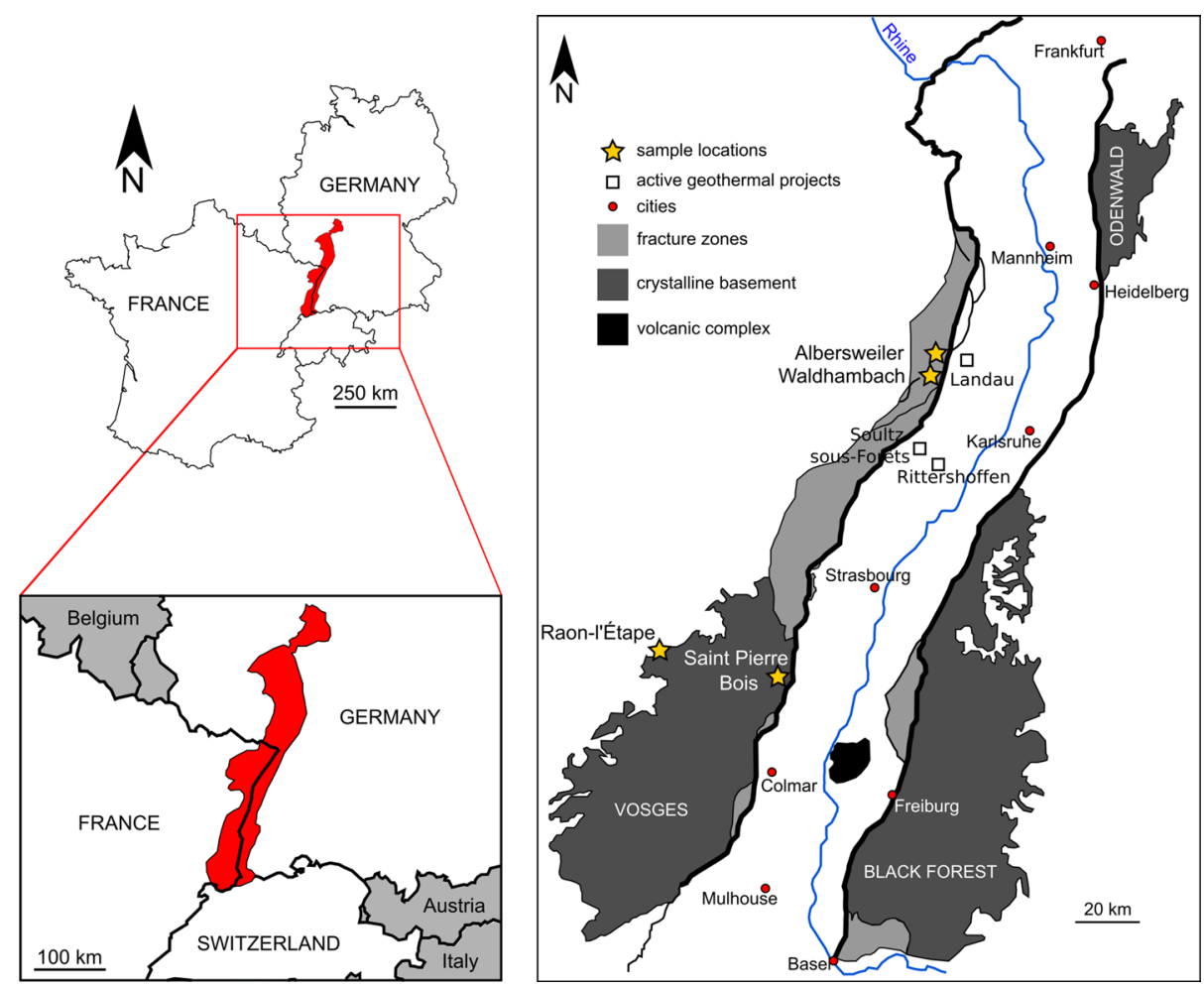

Fig. 1 Map of the Rhine Graben Basin, Europe. The location of the quarries of Saint Pierre Bois and Raon I'Etape in France and Waldhambach and Albersweiler in Germany are identified by the yellow stars

Germany), and Albersweiler (Baden-Württemberg, Germany) (Fig. 1). These rocks were chosen to represent the lithologies spanning the Paleozoic-to-Permo-Triassic transition at these locations and include sandstones, breccia, granites, metagranites, dolomites, and volcanic rocks.

The Waldhambach quarry (27 km north of Soultz-sous-Forêts) provides a clear expression of the Paleozoic biotite-amphibole granodiorite overlain, in turn, by (1) white- to purple-coloured, medium to coarse-grained Permian sandstones; (2) black-coloured hydrothermally altered Permian andesites; and finally (3) orange- to red-coloured fine to medium grained Buntsandstein sandstones and clayey sandstones (Fig. 2a).

At the Albersweiler quarry (34 km north of Soultz-sous-Forêts), the Hercynian basement is a crystalline complex that has been subjected to regional metamorphism under amphibolite facies conditions and consists of metabasites (plagioclase + hornblende + biotite + quartz) crosscut by aplitic dykes on the western portion of the quarry and metagranite (quartz + K-feldspar + plagioclase + biotite \pm hornblende) crosscut by mafic dykes in the eastern portion of the quarry (Fig. 2b) (Okrusch 1995). The Hercynian basement is overlain by Permian formations including light-grey to purple-coloured, fine to coarse grained sandstones, red to purple-coloured, poorly-sorted breccia and red/ purple-coloured, variably fractured, hydrothermally altered aphanitic volcanic rocks. The sandstones and breccia contain blocks of metagranite and metabasites that are likely associated with the near in situ erosion of the basement rock. 

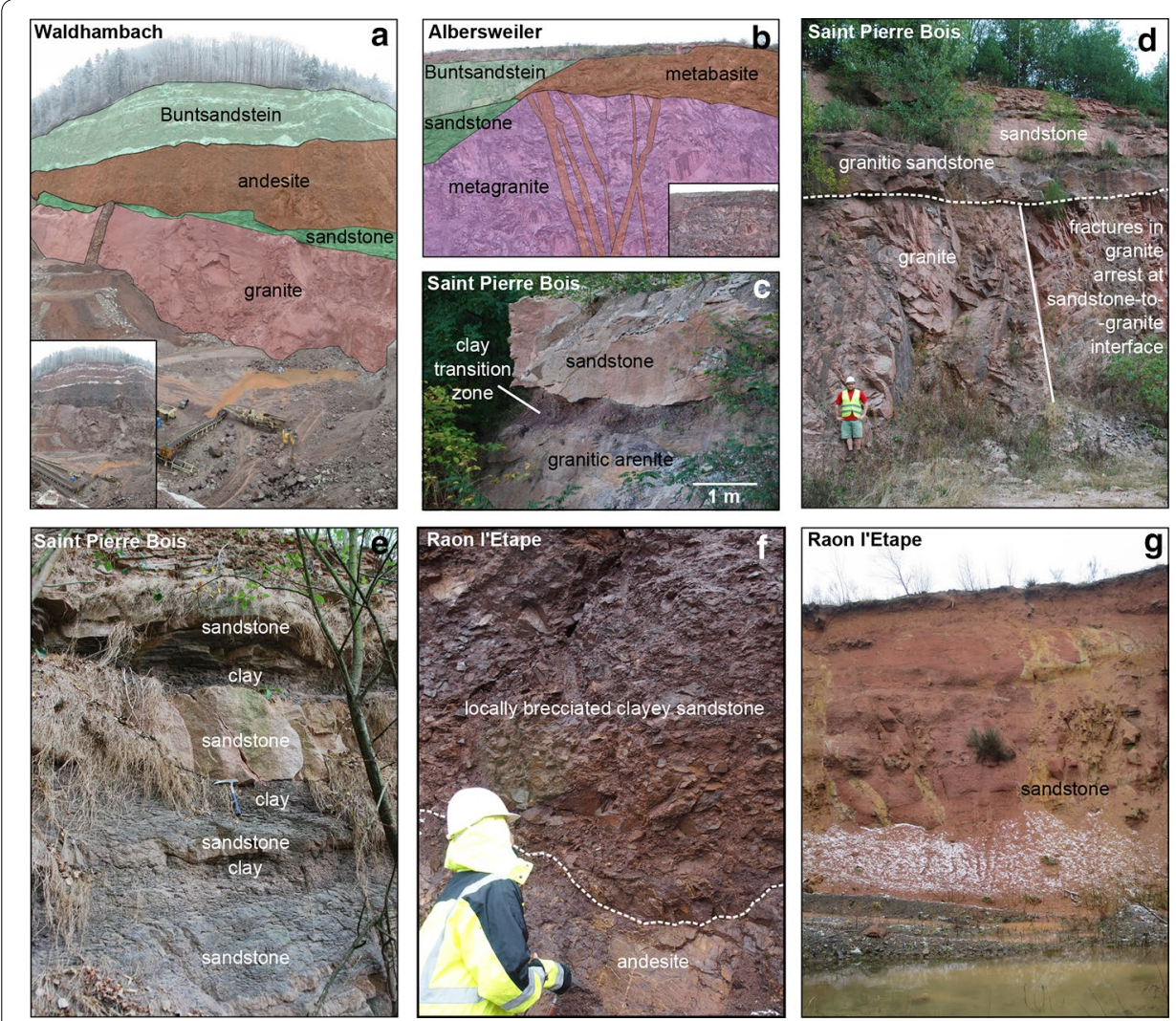

Fig. 2 Photos of the field locations from which the rock samples were taken. The dominant lithologies at each site are indicated. a Waldhambach, Germany. b Albersweiler, Germany. c Saint Pierre Bois, France. d Saint Pierre Bois, France. Note the fractures present in the granite become arrested at the sandstone-granite interface. e Saint Pierre Bois, France. Note the alternating sandstone and clay units. f Raon l'Etape, France. $\mathbf{g}$ Raon l'Etape, France

At Saint Pierre Bois (76 km south of Soultz-sous-Forêts), the crystalline basement consists of a coarse-grained, biotite-muscovite-bearing granite. This crystalline basement is overlain, in turn, by a granitic sandstone up to $1 \mathrm{~m}$ in thickness, a $30 \mathrm{~cm}$ thick layer of silty clay, and light grey to purple-coloured, fine to coarse-grained Permian sandstones (Fig. 2c). We note that the textural similarity between the granitic sandstone and the granite basement makes these two units difficult to distinguish from each other. Large-scale fracture networks crosscut the granite and terminate at the granite-sandstone interface (Fig. 2d). Locally, sandstone and silty clay layers are interbedded on the decimetre-scale (Fig. 2e).

The Hercynian basement at the quarry at Raon l'Etape $(96 \mathrm{~km}$ southwest of Soultzsous-Forêts) is made up of vertically tilted Devonian-Dinantian (360 Ma) andesites. The subsequent erosion of this basement produced breccia (Fig. 2f) that is Permian in age and deposited exclusively in areas of negative relief along the Devonian-Dinantian to Permian paleosurface. Elsewhere, the basement is overlain by a yellow to browncoloured, poorly lithified but well sorted, medium-grained Buntsandstein sandstone (Fig. 2g). Locally, dolomite-filled fractures crosscut the basement and the sedimentary cover, and are associated with the near-complete dolomitization of the breccia. 
We have sampled rocks that are unique and representative of the diversity of the lithologies extant at each quarry site. In those cases where rocks are comparable between sites, we have opted not to resample them but, instead, have assumed that they are representative of all sites. For example, the crystalline basement at all sites is either granite or metagranite, thus we have only sampled the granites from Saint Pierre Bois and the metagranites from Albersweiler. In total, 10 different lithologies were sampled from the four quarry sites for physical property characterisation (Fig. 3; Table 1).

\section{Mineralogical characterisation and microstructural analysis}

Mineral content was determined using X-ray powder diffraction (XRPD) patterns of bulk rock powder. Bulk rock samples of each lithology were ground for 8 min with $10 \mathrm{ml}$ of isopropyl alcohol using agate cylinders in a McCrone Micronising Mill. XRPD analyses were performed on powder mounts using a PW $1800 \mathrm{X}$-ray diffractometer $(\mathrm{CuK} \alpha$, graphite monochromator, $10 \mathrm{~mm}$ automatic divergence slit, step-scan $0.02^{\circ} 2 \theta$ increments per second, counting time one second per increment, $40 \mathrm{~mA}, 40 \mathrm{kV}$ ) and mineral phases were quantified by Rietveld analysis using the program BGMN (Bergmann et al. 1998). Clay minerals were identified by separating the $<2 \mu \mathrm{m}$ particle fraction using a centrifuge and preparing oriented mounts that were X-rayed in an air-dried and ethylene glycolated state.

Double-polished thin sections were prepared for select samples (Table 1) and the predominant microstructural characteristics were examined using a Tescan Vega 2 XMU scanning electron microscope (SEM).

\section{Sample preparation and porosity measurements}

We prepared a total of 100 cylindrical rock samples out of the 10 lithologies collected in the field. Samples were cored in three mutually perpendicular directions; these directions are denoted as the $x$-, $y$-, or $z$-direction with the $x$-direction taken perpendicular to any observed bedding or foliation (Table 2). In rocks that did not display any evident bedding or foliation, the $x$-, $y$-, $z$-directions were assigned arbitrarily. The cylindrical samples had a diameter of $20 \mathrm{~mm}$ and their ends were ground flat to a nominal

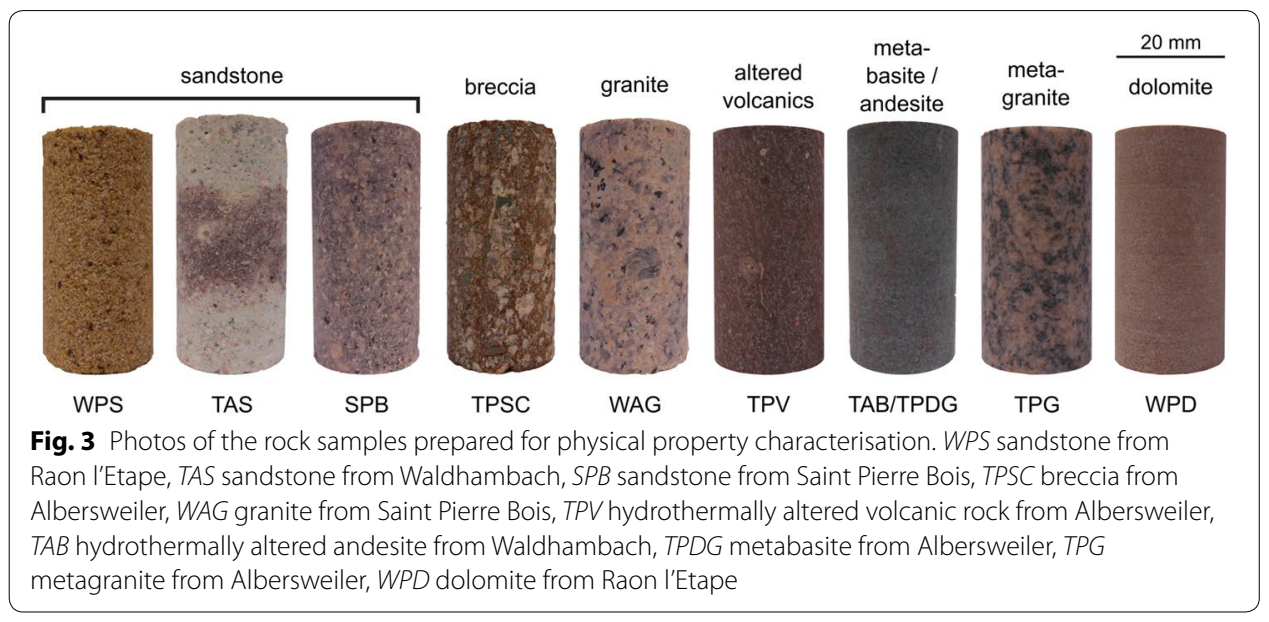




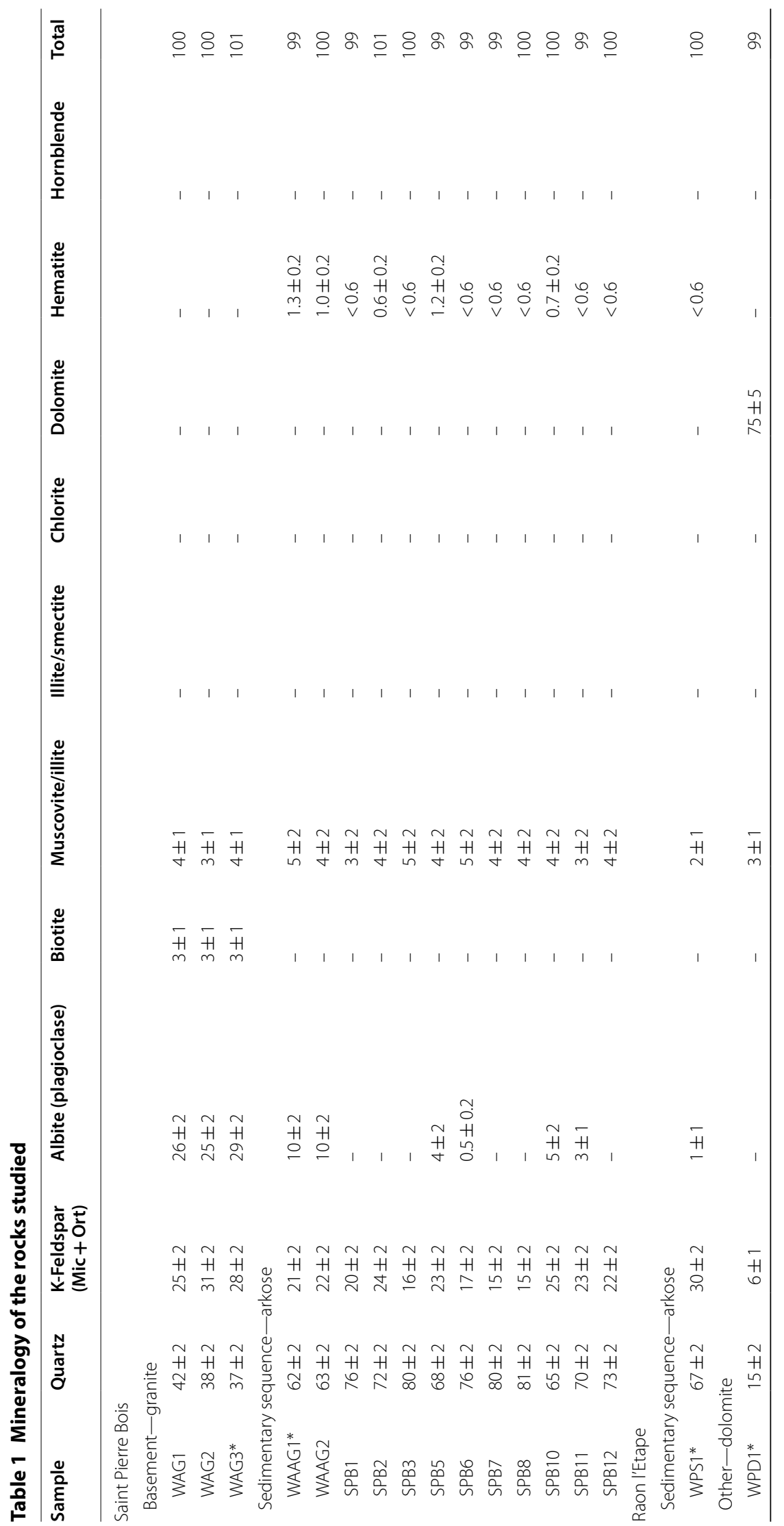




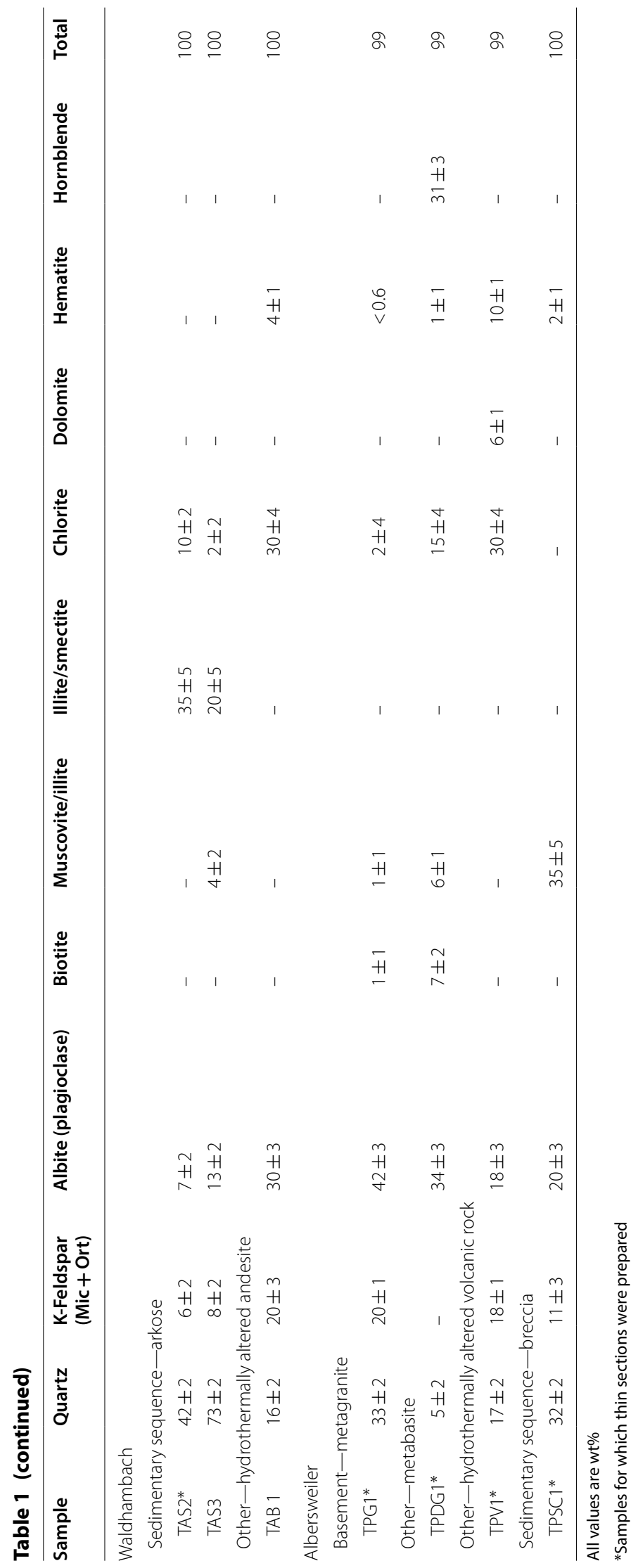


Table 2 Physical properties measured on the oriented core samples

\begin{tabular}{|c|c|c|c|c|c|c|}
\hline Sample & $\begin{array}{l}\text { Direction } \\
\text { of coring }\end{array}$ & $I(\mathrm{~mm})$ & $d(\mathrm{~mm})$ & $\varphi_{\mathrm{c}}$ & $\varphi_{\mathrm{t}}$ & $V_{p}\left(\mathrm{~km} \mathrm{~s}^{-1}\right)$ \\
\hline \multicolumn{7}{|c|}{ Saint Pierre Bois (France) } \\
\hline \multicolumn{7}{|c|}{ Basement—granite } \\
\hline WAG1_1 & $x$ & 40.09 & 19.81 & 0.03 & 0.04 & 4.52 \\
\hline WAG1_2 & $x$ & 40.09 & 19.82 & 0.04 & 0.04 & 4.39 \\
\hline WAG1_3 & Y & 39.84 & 19.83 & 0.04 & 0.04 & 4.69 \\
\hline WAG1_4 & Y & 40.16 & 19.84 & 0.03 & 0.03 & 4.73 \\
\hline WAG1_5 & Z & 40.06 & 19.73 & 0.03 & 0.03 & 4.84 \\
\hline WAG1_6 & $Z$ & 39.99 & 19.71 & 0.03 & 0.04 & 4.80 \\
\hline WAG2_1 & $x$ & 40.02 & 19.75 & 0.05 & 0.05 & 4.51 \\
\hline WAG2_2 & $x$ & 40.04 & 19.73 & 0.03 & 0.04 & 4.82 \\
\hline WAG2_3 & Y & 40.01 & 19.75 & 0.04 & 0.04 & 4.86 \\
\hline WAG2_4 & Y & 40.02 & 19.74 & 0.05 & 0.05 & 4.71 \\
\hline WAG2_5 & Z & 40.05 & 19.73 & 0.05 & 0.05 & 4.84 \\
\hline WAG2_6 & Z & 40.16 & 19.74 & 0.03 & 0.04 & 4.90 \\
\hline WAG3_1 & $x$ & 39.99 & 19.93 & 0.02 & 0.03 & 5.20 \\
\hline WAG3_2 & $x$ & 40.09 & 19.93 & 0.03 & 0.03 & 5.16 \\
\hline WAG3_3 & Y & 39.97 & 19.80 & 0.02 & 0.03 & 5.05 \\
\hline WAG3_4 & Y & 40.13 & 19.80 & 0.03 & 0.03 & 4.92 \\
\hline WAG3_5 & Z & 40.07 & 19.94 & 0.03 & 0.03 & 5.04 \\
\hline WAG3_6 & Z & 40.08 & 19.94 & 0.02 & 0.03 & 5.08 \\
\hline \multicolumn{7}{|c|}{ Sedimentary sequence - arkose } \\
\hline WAAG1_1 & $x$ & 40.04 & 19.78 & 0.03 & 0.03 & 3.90 \\
\hline WAAG1_2 & $x$ & 40.08 & 19.77 & 0.03 & 0.03 & 3.96 \\
\hline WAAG1_3 & Y & 40.11 & 19.78 & 0.03 & 0.03 & 4.18 \\
\hline WAAG1_4 & Y & 40.08 & 19.79 & 0.03 & 0.03 & 4.32 \\
\hline WAAG1_5 & Z & 40.01 & 19.70 & 0.03 & 0.03 & 4.23 \\
\hline WAAG1_6 & Z & 40.02 & 19.68 & 0.03 & 0.03 & 4.22 \\
\hline WAAG2_1 & $x$ & 40.07 & 19.95 & 0.04 & 0.04 & 3.76 \\
\hline WAAG2_2 & Y & 40.05 & 19.94 & 0.04 & 0.04 & 3.74 \\
\hline WAAG2_3 & Z & 40.08 & 19.97 & 0.03 & 0.04 & 3.96 \\
\hline SPB1_1 & $x$ & 40.04 & 19.91 & 0.08 & 0.08 & 4.38 \\
\hline SPB1_2 & Y & 40.04 & 19.92 & 0.08 & 0.09 & 4.52 \\
\hline SPB1_3 & $Z$ & 40.03 & 19.93 & 0.09 & 0.09 & 4.59 \\
\hline SPB2_1 & $x$ & 40.08 & 19.99 & 0.09 & 0.09 & 4.38 \\
\hline SPB2_2 & Y & 40.05 & 19.99 & 0.09 & 0.10 & 4.39 \\
\hline SPB2_3 & Z & 40.11 & 20.02 & 0.09 & 0.09 & 4.49 \\
\hline SPB3_1 & $x$ & 40.18 & 20.09 & 0.12 & 0.13 & 3.80 \\
\hline SPB3_2 & Y & 40.08 & 20.11 & 0.13 & 0.13 & 3.73 \\
\hline SPB3_3 & $Z$ & 40.12 & 20.11 & 0.13 & 0.13 & 3.85 \\
\hline SPB5_1 & Y & 39.93 & 19.98 & 0.05 & 0.05 & 4.59 \\
\hline SPB5_2 & Z & 40.10 & 20.00 & 0.05 & 0.05 & 4.56 \\
\hline SPB6_1 & $x$ & 40.03 & 20.06 & 0.13 & 0.14 & 3.80 \\
\hline SPB6_2 & $Y$ & 40.03 & 20.06 & 0.13 & 0.14 & 3.99 \\
\hline SPB6_3 & $Z$ & 40.16 & 20.07 & 0.14 & 0.14 & 3.90 \\
\hline SPB7_1 & $x$ & 39.90 & 19.94 & 0.13 & 0.14 & 3.73 \\
\hline SPB7_2 & Y & 40.09 & 19.94 & 0.13 & 0.14 & 3.71 \\
\hline SPB7_3 & $Z$ & 40.15 & 19.97 & 0.14 & 0.14 & 3.81 \\
\hline SPB8_1 & $x$ & 38.94 & 20.07 & 0.12 & 0.12 & 3.96 \\
\hline SPB8_2 & Y & 40.10 & 20.10 & 0.13 & 0.13 & 3.76 \\
\hline
\end{tabular}


Table 2 (continued)

\begin{tabular}{|c|c|c|c|c|c|c|}
\hline Sample & $\begin{array}{l}\text { Direction } \\
\text { of coring }\end{array}$ & $I(\mathrm{~mm})$ & $d(\mathrm{~mm})$ & $\varphi_{\mathrm{c}}$ & $\varphi_{\mathrm{t}}$ & $V_{\mathrm{p}}\left(\mathrm{km} \mathrm{s}^{-1}\right)$ \\
\hline SPB8_3 & $Z$ & 40.03 & 20.07 & 0.12 & 0.12 & 3.90 \\
\hline SPB10_1 & $x$ & 40.12 & 20.01 & 0.05 & 0.05 & 4.01 \\
\hline SPB10_2 & Y & 40.09 & 20.02 & 0.05 & 0.05 & 4.26 \\
\hline SPB10_3 & Z & 40.09 & 20.01 & 0.05 & 0.06 & 4.36 \\
\hline SPB11_1 & $x$ & 40.13 & 20.12 & 0.05 & 0.06 & 4.80 \\
\hline SPB11_2 & Y & 40.02 & 20.13 & 0.06 & 0.06 & 4.70 \\
\hline SPB11_3 & Z & 40.11 & 21.37 & 0.16 & 0.17 & 4.63 \\
\hline SPB12_1 & Y & 39.99 & 20.09 & 0.09 & 0.09 & 4.10 \\
\hline SPB12_2 & $z$ & 40.08 & 20.09 & 0.09 & 0.09 & 4.10 \\
\hline \multicolumn{7}{|c|}{ Raon l'Etape (France) } \\
\hline \multicolumn{7}{|c|}{ Sedimentary sequence_-arkose } \\
\hline WPS1_1 & $x$ & 40.01 & 19.76 & 0.25 & 0.25 & 1.77 \\
\hline WPS1_2 & Y & 40.03 & 19.72 & 0.25 & 0.25 & 1.97 \\
\hline WPS1_3 & Z & 39.97 & 19.72 & 0.25 & 0.25 & 1.99 \\
\hline \multicolumn{7}{|c|}{ Other-dolomite } \\
\hline WPD1_1 & $x$ & 40.07 & 19.96 & 0.02 & 0.03 & 5.27 \\
\hline WPD1_2 & Y & 40.05 & 19.94 & 0.02 & 0.02 & 5.15 \\
\hline WPD1_3 & Z & 40.14 & 19.96 & 0.02 & 0.03 & 5.45 \\
\hline \multicolumn{7}{|c|}{ Waldhambach (Germany) } \\
\hline \multicolumn{7}{|c|}{ Sedimentary sequence_-arkose } \\
\hline TAS1_1 & $x$ & 39.76 & 19.88 & 0.15 & 0.15 & 3.25 \\
\hline TAS1_2 & Y & 39.94 & 19.92 & 0.15 & 0.15 & 3.48 \\
\hline TAS1_3 & $Z$ & 40.02 & 19.88 & 0.14 & 0.15 & 3.82 \\
\hline TAS2_1 & Y & 40.02 & 19.79 & 0.12 & 0.10 & 3.66 \\
\hline TAS2_2 & Y & 40.06 & 19.74 & 0.11 & 0.10 & 3.68 \\
\hline TAS2_3 & Y & 42.04 & 19.09 & 0.04 & 0.04 & 3.49 \\
\hline TAS2_4 & Z & 40.16 & 19.91 & 0.12 & 0.12 & 3.73 \\
\hline TAS2_5 & Z & 40.09 & 19.94 & 0.12 & 0.12 & 3.55 \\
\hline TAS3_1 & $x$ & 40.19 & 19.72 & 0.13 & 0.13 & 3.58 \\
\hline TAS3_2 & $x$ & 39.23 & 19.77 & 0.14 & 0.13 & 3.38 \\
\hline TAS3_3 & Y & 40.05 & 19.78 & 0.14 & 0.13 & 3.76 \\
\hline TAS3_4 & Y & 40.06 & 19.78 & 0.14 & 0.13 & 4.00 \\
\hline TAS3_5 & Z & 42.00 & 19.74 & 0.11 & 0.10 & 3.97 \\
\hline TAS3_6 & Z & 40.15 & 19.78 & 0.14 & 0.13 & 3.96 \\
\hline TAS3_7 & Z & 40.11 & 19.77 & 0.13 & 0.12 & 3.84 \\
\hline \multicolumn{7}{|c|}{ Other—hydrothermally altered andesite } \\
\hline TAB 1_1 & $x$ & 40.00 & 20.03 & 0.00 & 0.02 & 5.02 \\
\hline TAB 1_2 & Y & 40.10 & 20.01 & 0.00 & 0.01 & 5.09 \\
\hline TAB 1_3 & Z & 40.10 & 20.03 & 0.00 & 0.02 & 4.85 \\
\hline \multicolumn{7}{|c|}{ Albersweiler (Germany) } \\
\hline \multicolumn{7}{|c|}{ Basement—metagranite } \\
\hline TPG1_1 & $x$ & 40.03 & 19.63 & 0.00 & 0.01 & 5.37 \\
\hline TPG1_2 & Y & 40.11 & 19.94 & 0.00 & 0.01 & 5.76 \\
\hline TPG1_3 & Z & 40.06 & 19.96 & 0.00 & 0.01 & 5.75 \\
\hline TPG2_1 & $x$ & 40.01 & 19.98 & 0.00 & 0.00 & 5.50 \\
\hline TPG2_2 & Y & 40.09 & 20.01 & 0.00 & 0.00 & 5.69 \\
\hline TPG2_3 & $z$ & 40.09 & 20.04 & 0.00 & 0.00 & 5.79 \\
\hline \multicolumn{7}{|c|}{ Other-metabasite } \\
\hline TPDG1_1 & $x$ & 40.15 & 19.89 & 0.00 & 0.01 & 5.88 \\
\hline
\end{tabular}


Table 2 (continued)

\begin{tabular}{|c|c|c|c|c|c|c|}
\hline Sample & $\begin{array}{l}\text { Direction } \\
\text { of coring }\end{array}$ & $I(\mathrm{~mm})$ & $d(\mathrm{~mm})$ & $\varphi_{\mathrm{c}}$ & $\varphi_{\mathrm{t}}$ & $V_{\mathrm{p}}\left(\mathrm{km} \mathrm{s}^{-1}\right)$ \\
\hline TPDG1_2 & $x$ & 40.02 & 19.89 & 0.00 & 0.01 & 6.11 \\
\hline TPDG1_3 & Y & 40.04 & 19.89 & 0.00 & 0.00 & 6.11 \\
\hline TPDG1_4 & Y & 40.11 & 19.89 & 0.00 & 0.00 & 6.20 \\
\hline TPDG1_5 & Z & 40.07 & 19.78 & 0.00 & 0.01 & 5.77 \\
\hline TPDG1_6 & Z & 40.05 & 19.78 & 0.00 & 0.00 & 6.15 \\
\hline \multicolumn{7}{|c|}{ Other-hydrothermally altered volcanic rock } \\
\hline TPV1_1 & $x$ & 40.12 & 19.92 & 0.15 & 0.15 & 3.46 \\
\hline TPV1_2 & Y & 38.37 & 19.92 & 0.17 & 0.16 & - \\
\hline TPV1_3 & $z$ & 40.11 & 19.90 & 0.16 & 0.16 & 3.52 \\
\hline \multicolumn{7}{|c|}{ Sedimentary sequence-breccia } \\
\hline TPSC1_1 & $x$ & 40.18 & 19.79 & 0.07 & 0.07 & 2.74 \\
\hline TPSC1_2 & $x$ & 40.16 & 19.73 & 0.06 & 0.06 & 2.96 \\
\hline TPSC1_3 & Y & 40.07 & 19.80 & 0.06 & 0.06 & 3.37 \\
\hline TPSC1_4 & Y & 40.08 & 19.82 & 0.10 & 0.09 & 3.33 \\
\hline TPSC1_5 & $Z$ & 40.08 & 19.79 & 0.07 & 0.07 & 2.34 \\
\hline TPSC1_6 & $Z$ & 40.03 & 19.78 & 0.06 & 0.07 & 2.43 \\
\hline
\end{tabular}

I and $d$ are the length and diameter of the cored samples, respectively; $\varphi_{c}$ is the connected gas porosity; $\varphi_{\mathrm{t}}$ is the total porosity; $V_{p}$ is the P-wave velocity

sample length of $40 \mathrm{~mm}$. Prior to all measurements described hereafter, all samples were cleaned with water and dried in a vacuum oven at $40{ }^{\circ} \mathrm{C}$ for at least $24 \mathrm{~h}$.

The connected porosity of all samples is: $\phi_{\mathrm{c}}=\left(1-\frac{V_{\mathrm{s}}}{V_{\mathrm{b}}}\right)$, where $V_{\mathrm{b}}$ is the bulk volume

of the sample (calculated using the sample dimensions) and $V_{\mathrm{s}}$ is the volume of the sample excluding all connected pore space (determined using a Micrometrics AccuPycII 1340 helium pycnometer). The total sample porosity, $\phi_{\mathrm{t}}$, for all cores was calculated: $\phi_{\mathrm{t}}=1-\frac{\rho_{\mathrm{b}}}{\rho_{\mathrm{s}}}$, where $\rho_{\mathrm{b}}$ is bulk sample density and $\rho_{\mathrm{s}}$ is the skeletal density of the sample. $\rho_{\mathrm{s}}$ was determined for each rock type by measuring the mass and volume (using the pycnometer) of a powdered sample.

\section{Permeability}

The gas permeability, $k$, of 47 samples (Table 3) was measured using a bench-top gas permeameter (Farquharson et al. 2016) designed to make measurements using either the steady state flow or transient pulse methods. For all measurements, both the confining pressure and pore fluid pressures were provided using nitrogen gas. All measurements were made under a confining pressure of $1 \mathrm{MPa}$ and at ambient laboratory temperature.

The steady state flow method was used for samples of relatively high permeability $\left(k>10^{-17} \mathrm{~m}^{2}\right)$. Using this method, a constant pore fluid pressure gradient, $\Delta P$, was imposed across each sample and the volumetric flow rate, $Q$, of gas flowing through the sample was monitored using a gas flowmeter. $\Delta P=P_{\mathrm{u}}-P_{\mathrm{d}}$, where $P_{\mathrm{u}}$ and $P_{\mathrm{d}}$ are the upstream and downstream pore fluid pressures, respectively. $P_{\mathrm{d}}$ for all measurements was atmospheric pressure and typical values of $\Delta P$ were between 0.005 and $0.2 \mathrm{MPa}$; $Q$ was measured for several imposed $\Delta P$. Permeability was then calculated for every $\Delta P$ using Darcy's Law for a compressible fluid: 
Table 3 Permeability and mechanical properties of selected sample

\begin{tabular}{|c|c|c|c|}
\hline Sample & $k\left(m^{2}\right)$ & UCS (MPa) & $E(\mathrm{GPa})$ \\
\hline \multicolumn{4}{|c|}{ Saint Pierre Bois } \\
\hline \multicolumn{4}{|c|}{ Basement_-granite } \\
\hline WAG1_1 & $4.83 \times 10^{-18}$ & 108 & 23.9 \\
\hline WAG1_2 & $1.05 \times 10^{-18}$ & 92 & 23.7 \\
\hline WAG1_6 & $2.49 \times 10^{-18}$ & 103 & 26.0 \\
\hline WAG2_1 & $4.16 \times 10^{-18}$ & 84 & 20.3 \\
\hline WAG2_6 & $6.37 \times 10^{-18}$ & 98 & 28.2 \\
\hline WAG3_1 & $1.73 \times 10^{-18}$ & 124 & 35.6 \\
\hline WAG3_4 & $1.32 \times 10^{-18}$ & 106 & 33.0 \\
\hline \multicolumn{4}{|c|}{ Sedimentary sequence-arkose } \\
\hline WAAG1_2 & $1.24 \times 10^{-18}$ & 161 & 18.7 \\
\hline WAAG2_1 & $2.19 \times 10^{-18}$ & 127 & 16.4 \\
\hline SPB1_1 & $7.69 \times 10^{-19}$ & 130 & 17.2 \\
\hline SPB2_1 & $7.66 \times 10^{-19}$ & 127 & 16.1 \\
\hline SPB3_1 & $1.83 \times 10^{-18}$ & 83 & 12.5 \\
\hline SPB6_1 & $3.93 \times 10^{-18}$ & 70 & 11.5 \\
\hline SPB7_1 & $1.26 \times 10^{-17}$ & 65 & 9.2 \\
\hline SPB8_1 & $1.32 \times 10^{-17}$ & 64 & 10.8 \\
\hline SPB10_1 & $9.72 \times 10^{-19}$ & 143 & 19.9 \\
\hline SPB11_1 & $7.16 \times 10^{-19}$ & 199 & 30.2 \\
\hline \multicolumn{4}{|l|}{ Raon l'Etape } \\
\hline \multicolumn{4}{|c|}{ Sedimentary sequence - arkose } \\
\hline WPS1_1 & $4.26 \times 10^{-13}$ & 17 & 2.4 \\
\hline WPS1_2 & $6.76 \times 10^{-13}$ & 16 & 4.1 \\
\hline WPS1_3 & $6.29 \times 10^{-13}$ & 11 & 3.7 \\
\hline \multicolumn{4}{|c|}{ Other-dolomite } \\
\hline WPD1_1 & $<10^{-19}$ & 201 & 36.0 \\
\hline \multicolumn{4}{|c|}{ Waldhambach } \\
\hline \multicolumn{4}{|c|}{ Sedimentary sequence-arkose } \\
\hline TAS1_1 & $4.26 \times 10^{-18}$ & 80 & 9.6 \\
\hline TAS1_2 & $1.69 \times 10^{-15}$ & 79 & 8.7 \\
\hline TAS1_3 & $5.23 \times 10^{-16}$ & - & - \\
\hline TAS2_1 & $2.22 \times 10^{-16}$ & 48 & 8.5 \\
\hline TAS2_2 & $5.01 \times 10^{-16}$ & - & - \\
\hline TAS2_3 & $1.39 \times 10^{-14}$ & 63 & 9.4 \\
\hline TAS2_4 & $1.26 \times 10^{-14}$ & - & - \\
\hline TAS2_5 & $2.18 \times 10^{-14}$ & 79 & 12.1 \\
\hline TAS3_1 & $7.37 \times 10^{-19}$ & - & - \\
\hline TAS3_2 & - & 67 & 12.0 \\
\hline TAS3_3 & $2.97 \times 10^{-16}$ & - & - \\
\hline TAS3_4 & $8.99 \times 10^{-18}$ & 54 & 8.6 \\
\hline TAS3_5 & $2.06 \times 10^{-14}$ & - & - \\
\hline TAS3_7 & $7.90 \times 10^{-17}$ & 71 & 11.8 \\
\hline \multicolumn{4}{|c|}{ Other_-hydrothermally altered andesite } \\
\hline TAB 1_1 & $<10^{-19}$ & 269 & 34.3 \\
\hline \multicolumn{4}{|c|}{ Albersweiler } \\
\hline \multicolumn{4}{|c|}{ Basement-metagranite } \\
\hline TPG2_2 & $<10^{-19}$ & 248 & 42.4 \\
\hline
\end{tabular}


Table 3 (continued)

\begin{tabular}{llll}
\hline Sample & $\boldsymbol{k}\left(\mathbf{m}^{\mathbf{2}}\right)$ & UCS (MPa) & $\boldsymbol{E}(\mathbf{G P a})$ \\
\hline Other_metabasite & & & \\
TPDG1_1 & $2.21 \times 10^{-16}$ & 204 & 35.3 \\
TPDG1_2 & $<10^{-19}$ & 241 & 41.2 \\
Other_hydrothermally altered volcanic rock & & \\
TPV1_1 & $4.20 \times 10^{-18}$ & 74 & 9.1 \\
TPV1_2 & $1.04 \times 10^{-15}$ & 72 & -0 \\
TPV1_3 & $5.15 \times 10^{-17}$ & - & \\
Sedimentary sequence-breccia & & & 3.3 \\
TPSC1_1 & $4.12 \times 10^{-16}$ & 31 & 7.1 \\
TPSC1_2 & $2.28 \times 10^{-18}$ & 50 & 5.6 \\
TPSC1_3 & $6.65 \times 10^{-16}$ & 40 & 5.0 \\
TPSC1_4 & 33 & 5.4 \\
TPSC1_5 & $2.93 \times 10^{-15}$ & 61 & 5.5 \\
TPSC1_6 & $3.27 \times 10^{-16}$ & 60 &
\end{tabular}

$k$ is permeability, UCS is uniaxial compressive strength, and $E$ is elastic modulus

$$
k_{\mathrm{D}}=\frac{Q}{P_{\mathrm{m}}\left(P_{\mathrm{u}}-P_{\mathrm{d}}\right)} \frac{\mu L P_{\mathrm{d}}}{A}
$$

where $k_{\mathrm{D}}$ is the permeability calculated for every $\Delta P, Q$ is the volumetric flow rate measured downstream of the sample, $P_{\mathrm{m}}$ is the mean pore fluid pressure (i.e. $\left.\left(P_{\mathrm{u}}+P_{\mathrm{d}}\right) / 2\right), \mu$ is the viscosity of the pore fluid (taken as the viscosity of nitrogen at $20{ }^{\circ} \mathrm{C}=1.76 \times 10^{-5} \mathrm{~Pa} \mathrm{~s}$ ), and $L$ and $A$ are the sample length and cross sectional area, respectively.

For samples with relatively low permeability $\left(\mathrm{k}<10^{-17} \mathrm{~m}^{2}\right)$, permeability was determined using the transient pulse method (Brace et al. 1968). Using this method, two pore fluid reservoirs of constant and known volumes are separated by a permeable rock sample; sample permeability is determined by monitoring the equilibration of the pore fluid pressures in the upstream and downstream reservoirs across the sample. In this study, the downstream pore fluid reservoir was of infinite volume and at atmospheric pressure. Using this pore fluid reservoir configuration, sample permeability is calculated:

$$
k_{\mathrm{D}}=\frac{2 L \mu}{A} \frac{V_{\mathrm{u}}}{P_{\mathrm{u}}^{2}-P_{\mathrm{d}}^{2}} \frac{\mathrm{d} P_{\mathrm{u}}}{\mathrm{d} t}
$$

where $V_{\mathrm{u}}$ is the volume of the upstream pore fluid reservoir and equal to $V_{\mathrm{u}}=\frac{P_{\mathrm{d}} \mathrm{Q}}{\partial P_{\mathrm{u} / \partial t}}$

(see Heap et al. (2017) for a full derivation of these equations). $P_{\mathrm{u}}$ was approximately $0.2 \mathrm{MPa}$ for all transient pulse measurements made in the present study.

When fluid flow through a rock sample is laminar, the permeability of the sample is given by Eqs. 1 and 2. However, non-laminar gas flow may give rise to erroneous permeability values, necessitating the use of fluid flow corrections. In this study, we have assessed all permeability measurements for artefacts induced by turbulent flow (i.e. the Forchheimer effect; Forchheimer (1901)) and/or gas slip along flow channel walls (i.e. the Klinkenberg effect; Klinkenberg (1941)). Both the steady state flow and transient pulse 
methods give $k_{\mathrm{D}}$ for different values of $\Delta P$; this data is used to assess the need for fluid flow related corrections. The presence of the Forchheimer effect is assessed first. This is done by plotting $1 / k_{\mathrm{D}}$ as a function of $Q$ for every interval of $\Delta P$. A Forchheimer correction is necessary if the relationship between $1 / k_{\mathrm{D}}$ and $Q$ is well described by a positive linear relationship; we consider an $R^{2}>0.99$ to indicate a good correlation between $1 / k_{\mathrm{D}}$ and $Q$. The permeability of the sample corrected for the Forchheimer effect, $k_{\text {forch }}$, is the inverse of the $y$-intercept of the best-fit linear regression of this positive linear relationship.

To check for the Klinkenberg effect, a Forchheimer-corrected permeability, $k_{\mathrm{c}}$, is calculated for each $\triangle P$ :

$$
\frac{1}{k_{\mathrm{c}}}=\frac{1}{k_{\mathrm{D}}}-\xi Q
$$

where $\xi$ is the slope of the line of best fit that describes $1 / k_{\mathrm{D}}$ as a function of $Q$. Subsequently, $k_{\mathrm{c}}$ is assessed as a function of $1 / P_{\mathrm{m}}$ for every interval $\Delta P$. The Klinkenberg correction is necessary if the relationship between $k_{\mathrm{c}}$ and $1 / P_{m}$ is well described by a positive linear relationship (again, we consider an $\mathrm{R}^{2}>0.99$ to indicate a good correlation between $k_{\mathrm{c}}$ and $1 / P_{\mathrm{m}}$ ). If both the Forchheimer and Klinkenberg corrections are required, the sample permeability, $k$, is equal to the $y$-intercept of the best-fit linear regression of the relationship between $k_{\mathrm{c}}$ and $1 / P_{\mathrm{m}}$. If the relationship between $k_{\mathrm{c}}$ and $1 / P_{\mathrm{m}}$ cannot be described by a positive linear relationship, then only the Forchheimer correction is necessary and the permeability of the sample is $k=k_{\mathrm{forch}}$. In the absence of a Forchheimer correction, the need for a Klinkenberg correction is determined by assessing $k_{\mathrm{D}}$ as a function of $1 / P_{\mathrm{m}}$. In this case, the sample permeability, $k$, is the $y$-intercept of the best-fit linear regression of the relationship between $k_{\mathrm{D}}$ and $1 / P_{\mathrm{m}}$. If neither the Forchheimer nor the Klinkenberg correction is deemed necessary, then the sample permeability, $k$, is equal to $k_{\mathrm{D}}$.

\section{P-wave velocity}

The P-wave travel time along the length of all samples was measured using piezoelectric sensors excited at a frequency of $700 \mathrm{kHz}$. The time to the first arrival of the signal through the sample was used to calculate the P-wave velocity $\left(V_{\mathrm{p}}=\frac{L}{t_{\mathrm{p}}}\right.$, where $V_{\mathrm{p}}$ is the

P-wave velocity, $L$ is the sample length, and $t_{p}$ is the P-wave travel time). All measurements were conducted on oven-dry samples under a uniaxial stress of $\sim 1 \mathrm{MPa}$.

\section{Thermal properties}

The thermal conductivity $(\kappa)$ and diffusivity $(\alpha)$ of all lithologies was measured using the transient plane heat source (i.e. hot disk) method (Gustafsson 1991; ISO 22007-2 2015) using a Hot Disk TPS 500 apparatus. A $3.2 \mathrm{~mm}$ radius Kapton-insulated sensor was placed between the ends of two oven-dried cylindrical cores of each lithology; the sensor size allows for the accurate measurement of samples $20 \mathrm{~mm}$ in diameter. The output power used was between 150 and $220 \mathrm{~mW}$ and measurement times ranged between 


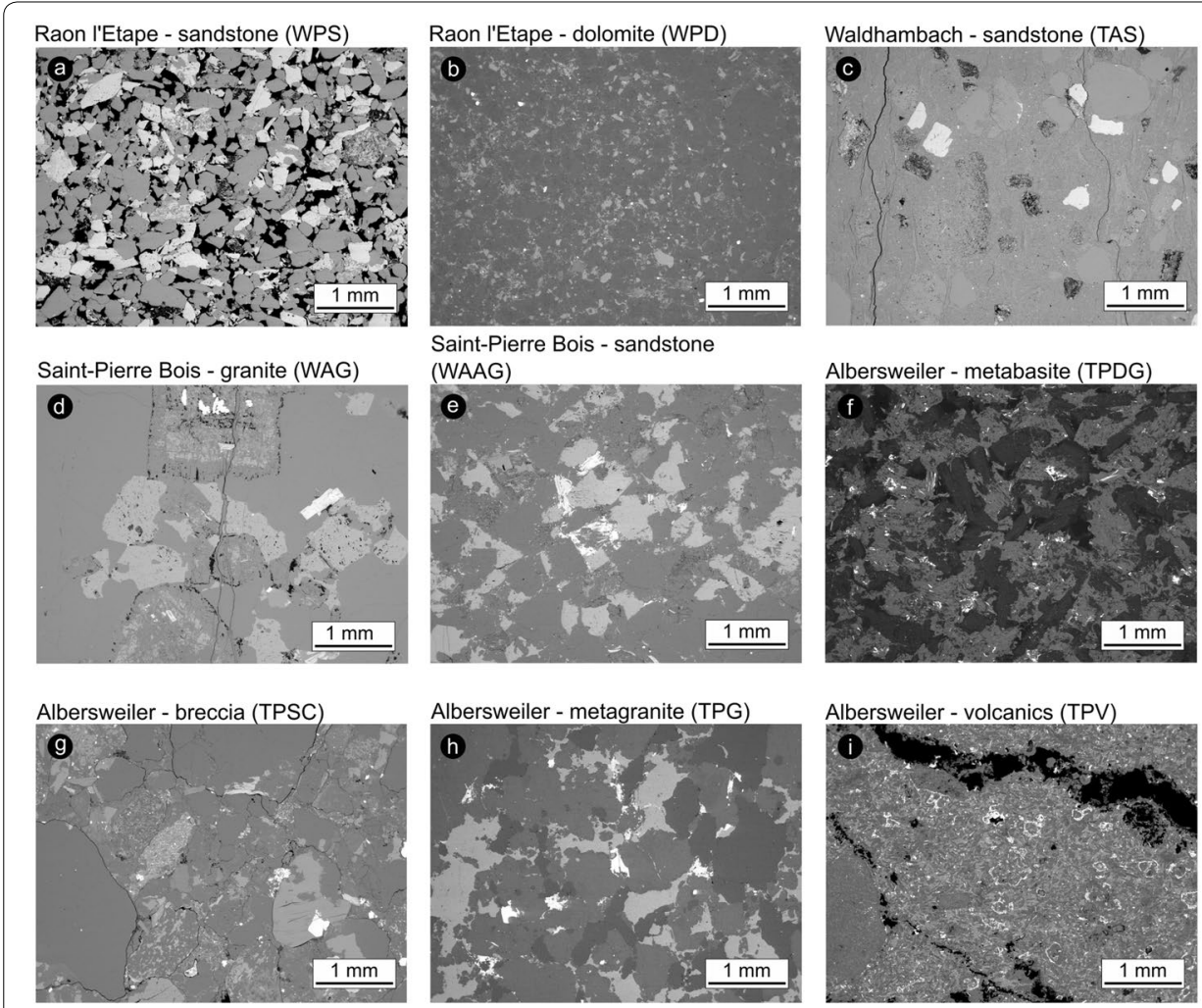

Fig. 4 Backscatter electron microscope images of select rocks characterised in this study. Black space is porosity. a Sandstone (WPS) from Raon l'Etape. b Dolomite (WPD) from Raon l'Etape. c Sandstone (TAS) from Waldhambach. d Granite (WAG) from Saint Pierre Bois. e Sandstone (WAAG) from Saint Pierre Bois. f Metabasite (TPDG) from Albersweiler. $\mathbf{g}$ Breccia (TPSC) from Albersweiler. $\mathbf{h}$ Metagranite (TPG) from Albersweiler. $\mathbf{i}$ Hydrothermally altered Permian volcanics (TPV) from Albersweiler

2.5 and $5 \mathrm{~s}$; measurement parameters were optimized for each lithology on a case-bycase basis. The total temperature increase across all samples did not exceed $8{ }^{\circ} \mathrm{C}$ during measurement and four measurements were made for each lithology. All data were analysed using the program Hot Disk Thermal Analyser 7.3; the specific heat capacity $\left(C_{\mathrm{p}}\right)$ of each sample was calculated by the program using the values of thermal conductivity and diffusivity.

\section{Uniaxial compressive strength}

Forty-two samples (Table 3) were deformed uniaxially at a constant strain rate of $1.0 \times 10^{-5} \mathrm{~s}^{-1}$ until macroscopic failure in a servo-controlled deformation apparatus (described by Heap et al. (2014) and Farquharson et al. (2017)). The piston displacement was controlled and recorded using a linear variable differential transducer (LVDT) and the force on the sample was monitored using a load cell. The force on the sample and the displacement of the piston were converted to axial stress and axial strain, respectively, using the sample dimensions. Measurements were performed on oven-dried samples at room temperature. The elastic modulus, $E$, of each sample was determined by calculating the slope of the linear portion of the loading part of the stress-strain curve (Bieniawski et al. 2007). 

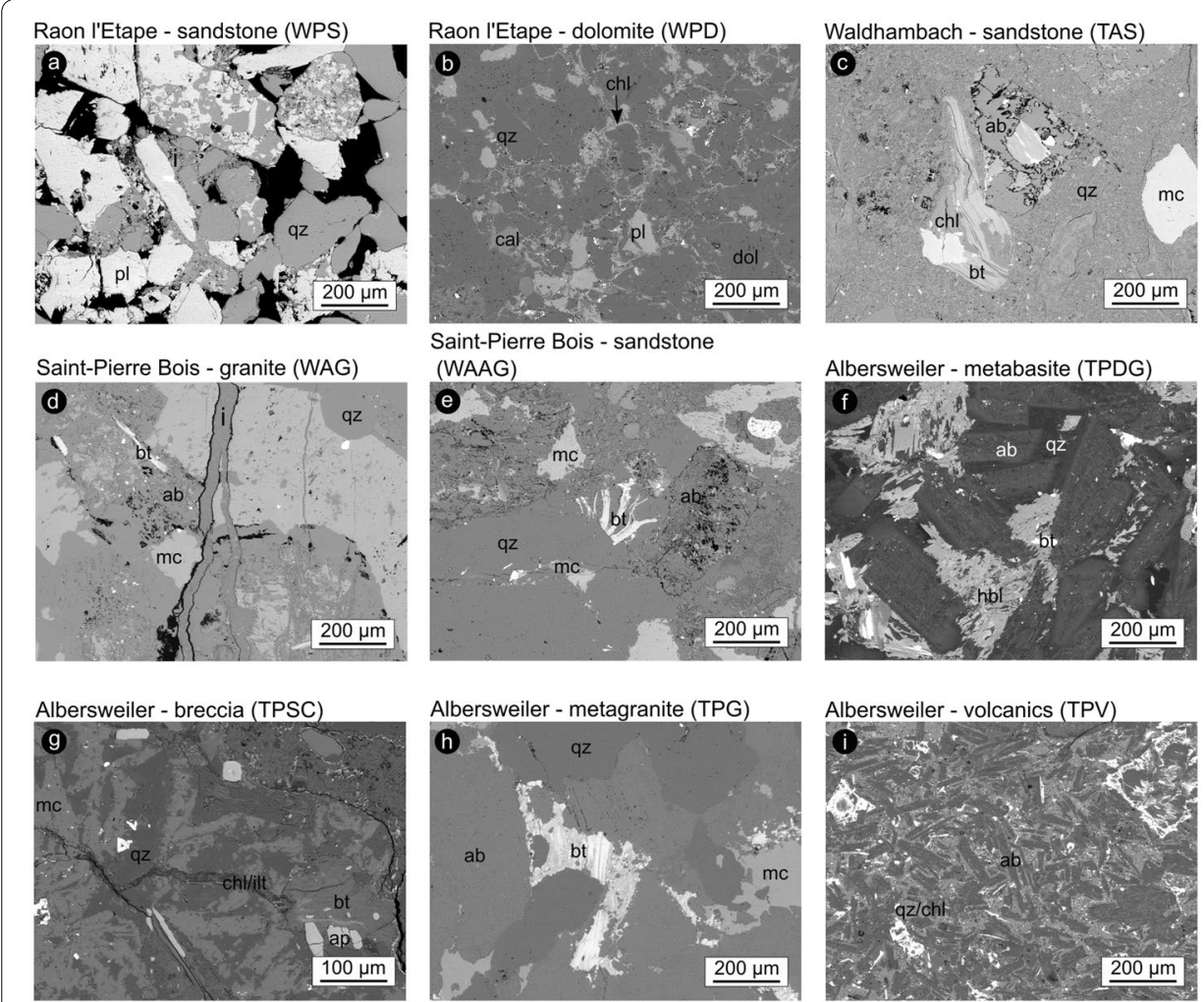

Fig. 5 Backscatter electron microscope images of select rocks characterised in this study. Black space is porosity. a Sandstone (WPS) from Raon l'Etape. b Dolomite (WPD) from Raon l'Etape. c Sandstone (TAS) from Waldhambach. d Granite (WAG) from Saint Pierre Bois. e Sandstone (WAAG) from Saint Pierre Bois. f Metabasite (TPDG) from Albersweiler. $\mathbf{g}$ Breccia (TPSC) from Albersweiler. $\mathbf{h}$ Metagranite (TPG) from Albersweiler. i Hydrothermally altered Permian volcanics (TPV) from Albersweiler. p/ plagioclase, qz quartz, chl chlorite, dol dolomite, cal calcite, mc microcline, bt biotite, ab albite, ilt illite, hbl hornblende

\section{Results}

We here describe the microstructural, mineralogical, and physical properties of the rocks studied, by location. For reference, the mineralogical data, as determined by XPRD, are given in Table 1. Backscattered electron images (BSE) of the samples are compiled in Figs. 4 and 5. The connected, porosity, total porosity, and P-wave velocity of all samples are given in Table 2. Permeability, UCS, and elastic modulus are given by field location in Table 3. Thermal property data are summarised in Table 4.

\section{Saint Pierre Bois (France)}

The Saint Pierre Bois granites contain quartz (37-42 wt\%), K-feldspar (25-31 wt\%), and albite (25-29 wt\%) with accessory biotite (3wt\%) and muscovite/illite (3-4 wt\%). Overall, their microstructure reflects a distinct lack of porosity (Fig. 4d) though, locally, illitefilled fractures are observed (Fig. 4d). Porosity in these samples is predominantly located along fractures and at the centre and edges of albite crystals (Figs. $4 \mathrm{~d}$ and $5 \mathrm{~d}$ ). Crystals are several $\mathrm{mm}$ in diameter.

The sandstone samples contain quartz (62-81 wt\%), K-feldspar (15-25 wt\%), variable amounts of plagioclase $(0.5-10 \mathrm{wt} \%$ albite), muscovite/illite (3-5 wt\%) with accessory 
Table 4 Thermal properties of the rocks

\begin{tabular}{|c|c|c|c|c|c|c|}
\hline Sample & 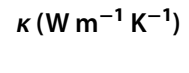 & $\sigma_{K}\left(W^{-1} \mathrm{~K}^{-1}\right)$ & $a\left(\mathrm{~mm}^{2} \mathrm{~s}^{-1}\right)$ & $\sigma_{a}\left(\mathrm{~mm}^{2} \mathrm{~s}^{-1}\right)$ & $C_{p}\left(\mathrm{MJm}^{-3} \mathrm{~K}^{-1}\right)$ & $\begin{array}{l}\sigma_{C p} \\
\left(\mathrm{MJ} \mathrm{m}^{-3} \mathrm{~K}^{-1}\right)\end{array}$ \\
\hline \multicolumn{7}{|c|}{ Saint Pierre Bois } \\
\hline \multicolumn{7}{|c|}{ Basement-granite } \\
\hline WAG1 & 3.44 & 0.18 & 1.59 & 0.10 & 2.18 & 0.22 \\
\hline WAG2 & 3.17 & 0.07 & 1.96 & 0.24 & 1.64 & 0.24 \\
\hline WAG3 & 3.22 & 0.08 & 1.60 & 0.10 & 2.01 & 0.18 \\
\hline \multicolumn{7}{|c|}{ Sedimentary sequence_-arkose } \\
\hline WAAG1 & 3.60 & 0.14 & 1.96 & 0.24 & 1.85 & 0.25 \\
\hline WAAG2 & 3.43 & 0.09 & 2.01 & 0.20 & 1.71 & 0.14 \\
\hline SPB1 & 3.60 & 0.06 & 2.34 & 0.12 & 1.54 & 0.06 \\
\hline SPB2 & 3.56 & 0.08 & 1.94 & 0.15 & 1.85 & 0.18 \\
\hline SPB3 & 3.19 & 0.03 & 1.83 & 0.13 & 1.75 & 0.12 \\
\hline SPB5 & 3.65 & 0.12 & 2.23 & 0.14 & 1.64 & 0.07 \\
\hline SPB6 & 2.94 & 0.24 & 2.18 & 0.15 & 1.35 & 0.17 \\
\hline SPB7 & 3.10 & 0.06 & 1.90 & 0.25 & 1.65 & 0.22 \\
\hline SPB8 & 3.18 & 0.08 & 2.07 & 0.16 & 1.54 & 0.16 \\
\hline SPB10 & 3.62 & 0.03 & 2.09 & 0.09 & 1.73 & 0.06 \\
\hline SPB11 & 3.66 & 0.02 & 2.21 & 0.10 & 1.66 & 0.08 \\
\hline SPB12 & 3.37 & 0.10 & 1.87 & 0.21 & 1.82 & 0.17 \\
\hline \multicolumn{7}{|c|}{ Raon l'Etape } \\
\hline \multicolumn{7}{|c|}{ Sedimentary sequence - arkose } \\
\hline WPS1 & 1.54 & 0.09 & 1.15 & 0.15 & 1.36 & 0.24 \\
\hline \multicolumn{7}{|c|}{ Other-dolomite } \\
\hline WPD1 & 3.88 & 0.08 & 1.68 & 0.04 & 2.31 & 0.03 \\
\hline \multicolumn{7}{|c|}{ Waldhambach } \\
\hline \multicolumn{7}{|c|}{ Sedimentary sequence - arkose } \\
\hline TAS1 & 2.32 & 0.08 & 1.37 & 0.04 & 1.70 & 0.09 \\
\hline TAS2 & 2.21 & 0.02 & 1.03 & 0.03 & 2.16 & 0.07 \\
\hline TAS3 & 2.44 & 0.14 & 1.41 & 0.07 & 1.74 & 0.10 \\
\hline \multicolumn{7}{|c|}{ Other-hydrothermally altered andesite } \\
\hline TAB 1 & 2.17 & 0.04 & 1.03 & 0.08 & 2.11 & 0.12 \\
\hline \multicolumn{7}{|c|}{ Albersweiler } \\
\hline \multicolumn{7}{|c|}{ Basement—metagranite } \\
\hline TPG1 & 2.93 & 0.03 & 1.74 & 0.12 & 1.69 & 0.11 \\
\hline TPG2 & 2.95 & 0.12 & 1.57 & 0.12 & 1.90 & 0.20 \\
\hline \multicolumn{7}{|c|}{ Other-metabasite } \\
\hline TPDG1 & 2.30 & 0.02 & 1.06 & 0.07 & 2.18 & 0.13 \\
\hline \multicolumn{7}{|c|}{ Other_-hydrothermally altered volcanic rock } \\
\hline TPV1 & 1.91 & 0.02 & 0.94 & 0.01 & 2.03 & 0.03 \\
\hline \multicolumn{7}{|c|}{ Sedimentary sequence — breccia } \\
\hline TPSC1 & 2.27 & 0.19 & 1.21 & 0.07 & 1.89 & 0.19 \\
\hline
\end{tabular}

All thermal property values are the average of four measurements; $k$ is thermal conductivity, $a$ is thermal diffusivity, and $C_{p}$ is specific heat capacity. $\sigma$ for each property is the standard deviation for the same four measurements

hematite $(<1.3 \mathrm{wt} \%)$. Their porosity is predominantly associated with the dissolution of albite; this is reflected in the variable amounts of albite detected by XRPD (Figs. 4e and $5 \mathrm{e})$. The grains in the sandstones are $<1 \mathrm{~mm}$ in diameter.

The connected porosity of the granites is between $0.02<\phi_{c}<0.05$ while the connected porosity of the sandstones is $0.03<\phi_{\mathrm{c}}<0.16$; in all samples, the isolated porosity 

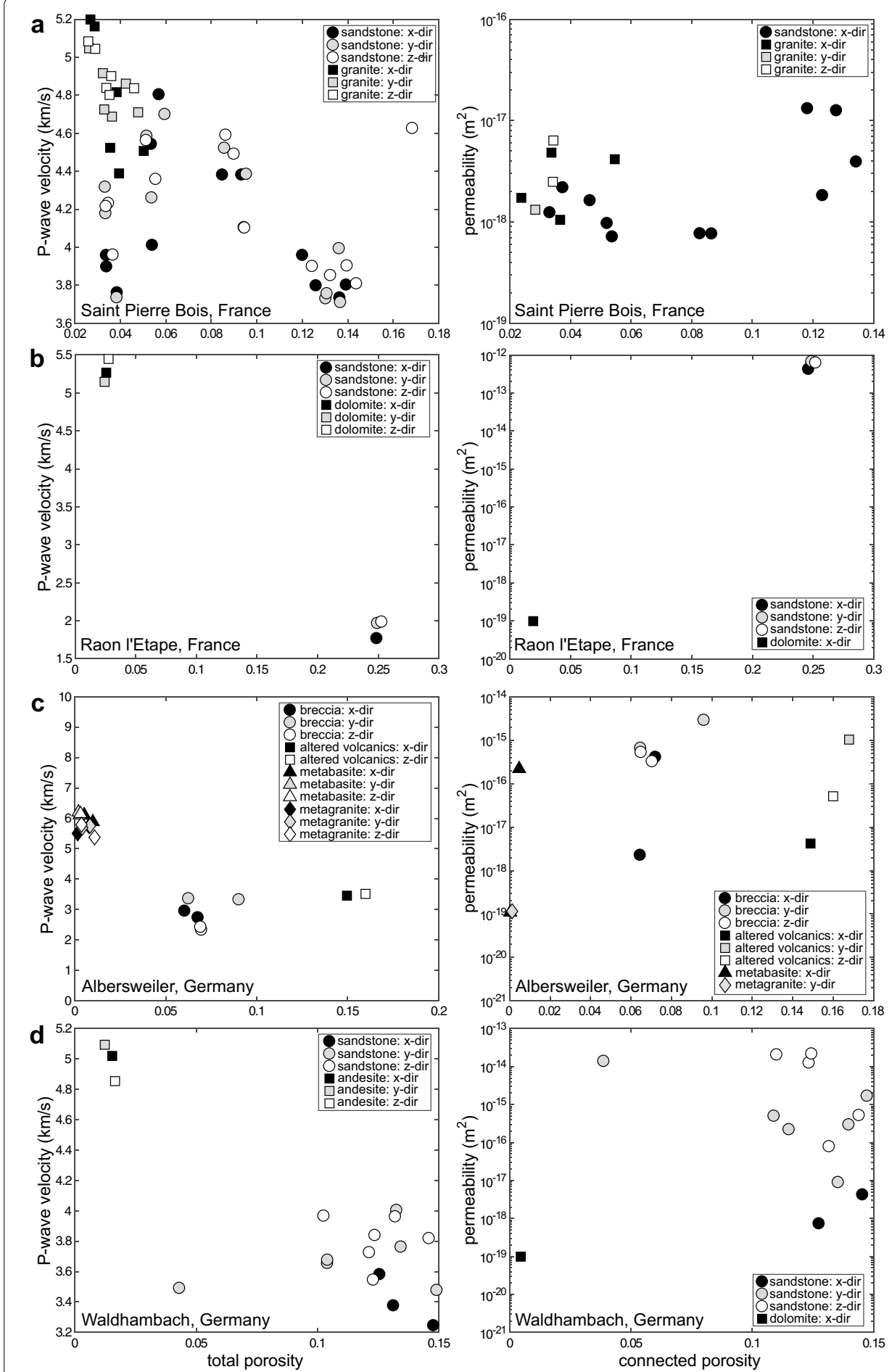

Fig. 6 P-wave velocity as a function of total porosity and permeability as a function of connected porosity for all rocks, organised by sample location. a Saint Pierre Bois. b Raon l'Etape. c Albersweiler. $\mathbf{d}$ Waldhambach 
does not exceed 0.01 . In general, P-wave velocity decreases with increasing porosity in both the granites and sandstones (Fig. 6). The P-wave velocity of the granites is consistently faster then that of the sandstones and ranges between $4.39<V_{\mathrm{p}}<5.20 \mathrm{~km} \mathrm{~s}^{-1}$. While the P-wave velocity of the sandstones generally decreases with increasing porosity $\left(3.71<V_{\mathrm{p}}<4.80 \mathrm{~km} \mathrm{~s}^{-1}\right)$, P-wave velocity may vary by as much as $1 \mathrm{~km} \mathrm{~s}^{-1}$ at low porosity $(<0.06)$. We do not observe P-wave velocity anisotropy in either of the lithologies. The permeability of the granites is between $1.05 \times 10^{-18}<k<6.37 \times 10^{-18} \mathrm{~m}^{2}$; the permeability of the sandstones is $7.16 \times 10^{-19}<k<1.32 \times 10^{-17} \mathrm{~m}^{2}$. We do not observe permeability anisotropy in the granites. Overall, the permeability of the sandstones increases with increasing porosity but does not vary by more than an order of magnitude over the entire porosity range. The permeability of the granites does not correlate with connected porosity and may vary by up to an order of magnitude for any given connected porosity. The sandstones have UCS between 64 and $199 \mathrm{MPa}$ and elastic modulus $(E)$ between 9 and $30 \mathrm{GPa}$. The granites have UCS between 84 and $124 \mathrm{MPa}$ and elastic modulus (E) between 20 and $36 \mathrm{GPa}$. Both parameters decrease with increasing porosity for each lithology.

The thermal conductivity of the sandstones is between $2.94<\kappa<3.66 \mathrm{~W} \mathrm{~m}^{-1} \mathrm{~K}^{-1}$, thermal diffusivity ranges between $1.83<\alpha<2.34 \mathrm{~mm}^{2} \mathrm{~s}^{-1}$, and specific heat capacity is between $1.35<C_{\mathrm{p}}<1.85 \mathrm{MJ} \mathrm{m}^{-3} \mathrm{~K}^{-1}$ (Table 4). Thermal properties of the sandstones are correlated with porosity (Fig. 7a). The thermal conductivity of the granites is between $3.17<\kappa<3.44 \mathrm{~W} \mathrm{~m}^{-1} \mathrm{~K}^{-1}$, thermal diffusivity ranges between $1.59<\alpha<1.96 \mathrm{~mm}^{2} \mathrm{~s}^{-1}$, and specific heat capacity is between $1.64<C_{\mathrm{p}}<2.18 \mathrm{MJ} \mathrm{m}^{-3} \mathrm{~K}^{-1}$ (Table 4).

\section{Raon l'Etape (France)}

The Raon l'Etape sandstones contain quartz (67 wt\%), K-feldspar (30 wt\%), and albite (1 wt\%) with accessory muscovite/illite (2 wt\%) (Table 1). Overall, their microstructure reflects a significant amount of pore space (Fig. 4a) that is only locally filled by clay minerals (Fig. 5a). Grains are generally less than one $\mathrm{mm}$ in diameter.

The dolomite samples contain dolomite (75 wt\%) with quartz (15 wt\%), K-feldspar (6 wt\%), and muscovite/illite ( $3 \mathrm{wt} \%)$. The dolomite is largely bereft of observable porosity (Fig. 4b). Its microstructure is dominated by dolomite grains less than one $\mathrm{mm}$ in diameter with rare chlorite seams observed between grains (Fig. 5b); chlorite was not abundant enough to be detected by XRPD.

Both the connected and total porosities of the sandstones are 0.25 while the connected porosity of the dolomite is 0.02 ; the isolated porosity in the dolomite does not exceed 0.01 . P-wave velocity is fastest in the dolomite and is between $5.15<V_{\mathrm{p}}<5.45 \mathrm{~km} \mathrm{~s}^{-1}$; in the sandstones, $\mathrm{P}$-wave velocity is $1.77<V_{\mathrm{p}}<1.99 \mathrm{~km} \mathrm{~s}^{-1}$ (Fig. 6). The permeability of the sandstones is between $4.26 \times 10^{-13}<k<6.76 \times 10^{-13} \mathrm{~m}^{2}$; the permeability of the dolomite is $<10^{-19} \mathrm{~m}^{2}$. The UCS of the sandstones is between 11 and $17 \mathrm{MPa}$; elastic modulus $(E)$ is between 2 and $4 \mathrm{GPa}$. The dolomite has a UCS of $201 \mathrm{MPa}$ and an elastic modulus $(E)$ of $36 \mathrm{GPa}$.

The thermal conductivity $(\kappa)$ of the sandstones is $1.54 \mathrm{~W} \mathrm{~m}^{-1} \mathrm{~K}^{-1}$, thermal diffusivity $(\alpha)$ is $1.15 \mathrm{~mm}^{2} \mathrm{~s}^{-1}$, and specific heat capacity $\left(C_{\mathrm{p}}\right)$ is $1.36 \mathrm{MJ} \mathrm{m}^{-3} \mathrm{~K}^{-1}$ (Table 4 ). The thermal conductivity $(\kappa)$ of the dolomite is $3.88 \mathrm{~W} \mathrm{~m} \mathrm{~m}^{-1} \mathrm{~K}^{-1}$, thermal diffusivity $(\alpha)$ is $1.68 \mathrm{~mm}^{2} \mathrm{~s}^{-1}$, and specific heat capacity $\left(C_{\mathrm{p}}\right)$ is $2.31 \mathrm{MJ} \mathrm{m}^{-3} \mathrm{~K}^{-1}$ (Table 4 ). 

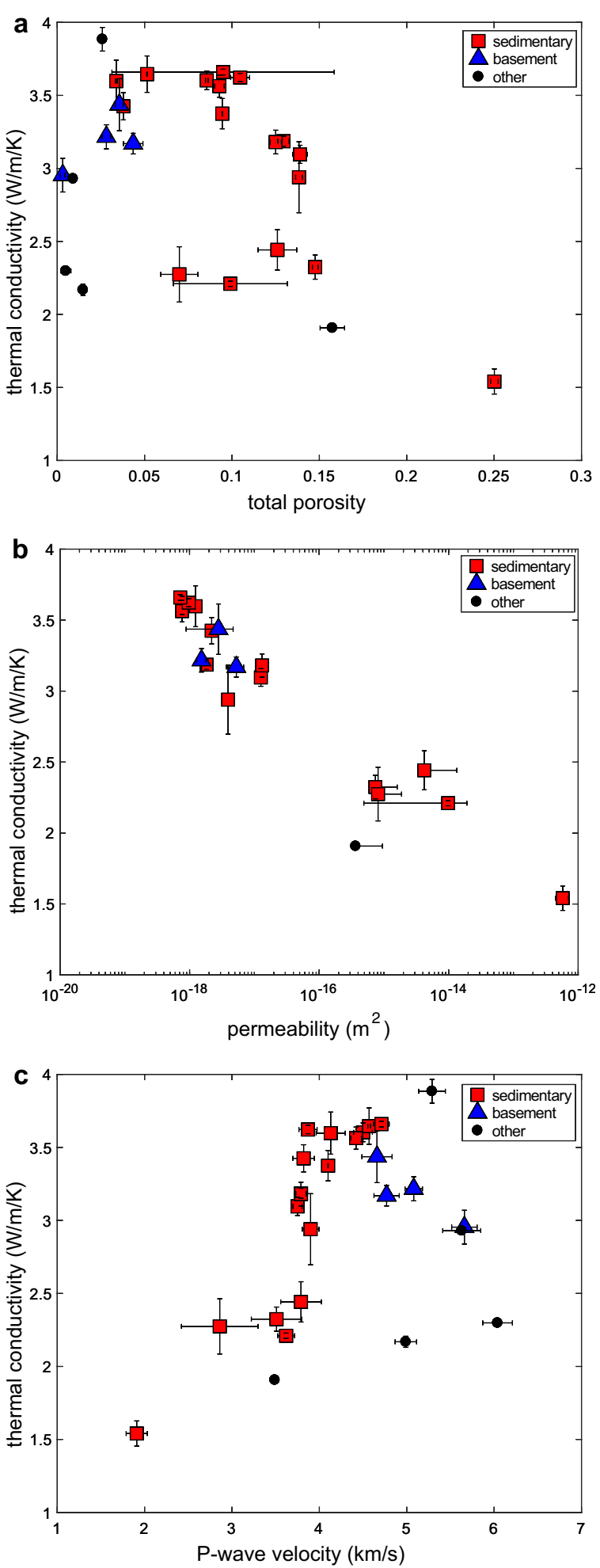

Fig. 7 Thermal conductivity of all rocks investigated as a function of $\mathbf{a}$ total porosity, $\mathbf{b}$ permeability, and c P-wave velocity. All rocks are categorised as either sedimentary (red squares), crystalline basement (blue triangles), or other lithologies (black circles); see Table 2. Thermal conductivity, porosity, permeability and P-wave velocities shown are the mean values for each rock type; error bars indicate the standard deviation of each mean value 


\section{Albersweiler (Germany)}

The Albersweiler metagranites contain quartz (33 wt\%), K-feldspar (20 wt\%), and albite (42 wt\%) with accessory biotite (1 wt\%), muscovite/illite (1 wt\%), chlorite ( $2 \mathrm{wt} \%)$, and hematite $(<0.6 \mathrm{wt} \%)$ (Table 1$)$. Overall, the metagranite microstructure reflects a conspicuous lack of porosity (Figs. $4 \mathrm{~h}$ and $5 \mathrm{~h}$ ). Crystals are $<1 \mathrm{~mm}$ in diameter.

Metabasites of the basement contain albite (34 wt\%), hornblende (31 wt\%), and chlorite (15 wt\%) with accessory quartz ( $5 \mathrm{wt} \%$ ), muscovite/illite (6 wt\%), biotite (7 wt\%), and hematite (1 wt\%). BSE images show an overall lack of porosity, though isolated porosity exists. Crystals are $<1 \mathrm{~mm}$ in diameter.

The hydrothermally altered Permian aphanitic volcanic samples contain quartz (17 wt\%), K-feldspar (11 wt\%), albite (18 wt\%), chlorite (30 wt\%), dolomite (6 wt\%), and hematite (10 wt\%). BSE images show a ubiquity of fractures running through an otherwise porosity-poor groundmass (Fig. 4i). The rock microstructure is characterised by albite crystals $<200 \mu \mathrm{m}$ long embedded in a quartz and chlorite groundmass (Fig. 5i).

Finally, the breccia samples contain quartz (32 wt\%), K-feldspar (11 wt\%), albite (20 wt\%), muscovite/illite (35 wt\%), and accessory hematite (2 wt\%). Overall, porosity in these samples is located at the edges of clasts (Fig. 4g); inter-clast fractures are locally filled by either chlorite or illite (Fig. $5 \mathrm{~g}$ ). Clasts are $>1 \mathrm{~mm}$ in diameter.

Neither the metagranites nor the metabasites at Albersweiler have appreciable connected porosity, though they both have total porosities up to 0.01 . The connected porosity of the hydrothermally altered Permian aphanitic volcanic rocks is between $0.15<\phi_{\mathrm{c}}<0.17$ while the connected porosity of the breccia is $0.06<\phi_{\mathrm{c}}<0.10$; in all samples, the isolated porosity does not exceed 0.01 . In general, P-wave velocity decreases with increasing porosity when all samples are compared (Fig. 6). The P-wave velocities of the metagranites and metabasites are similar and range between $5.37<V_{\mathrm{p}}<6.20 \mathrm{~km} \mathrm{~s}^{-1}$. The P-wave velocity through the hydrothermally altered Permian aphanitic volcanic rocks is between $3.46<V_{\mathrm{p}}<3.52 \mathrm{~km} \mathrm{~s}^{-1}$; The P-wave velocity through the breccia is between $2.34<V_{\mathrm{p}}<3.37 \mathrm{~km} \mathrm{~s}^{-1}$. We do not observe appreciable P-wave velocity anisotropy in any of the rocks. The permeability of both the metagranites and metabasites is $<10^{-19} \mathrm{~m}^{2}$, with the exception of one sample (TPDG1_1), which contains a throughgoing fracture along its length that raises the permeability by more than four orders of magnitude (Fig. 6). The permeability of the hydrothermally altered Permian aphanitic volcanic rocks is $4.20 \times 10^{-18}<k<1.04 \times 10^{-15} \mathrm{~m}^{2}$ and there appears to be permeability anisotropy associated with the direction of sample-scale filled fractures (Fig. 3; TPV); permeability perpendicular to the dominant plane of foliation is at least one order of magnitude less than in the $y$ - or $z$-directions. The permeability of the breccia is $2.28 \times 1$ $0^{-18}<k<2.93 \times 10^{-15} \mathrm{~m}^{2}$; in one of the $x$-direction samples, permeability is appreciably lower that the rest of the samples. Overall, permeability does not correlate with connected porosity for any of the dominant Albersweiler lithologies. The UCS of the various rocks are: $248 \mathrm{MPa}$ for the metagranites, 204-241 MPa for the metabasites, $71-74 \mathrm{MPa}$ for the hydrothermally altered Permian aphanitic volcanic rocks, and 31-61 MPa for the breccia. The elastic moduli of the various rocks are: $42.4 \mathrm{GPa}$ for the metagranites, 35.3-41.2 GPa for the metabasites, 9.0-9.1 GPa for the hydrothermally altered Permian aphanitic volcanic rocks, and 3.3-7.1 GPa for the breccia. 
Thermal conductivity for the rocks from Albersweiler is between $1.91<\kappa<2.95$ $\mathrm{W} \mathrm{m}{ }^{-1} \mathrm{~K}^{-1}$, thermal diffusivity ranges between $0.94<\alpha<1.74 \mathrm{~mm}^{2} \mathrm{~s}^{-1}$, and specific heat capacity is between $1.69<C_{\mathrm{p}}<2.18 \mathrm{MJ} \mathrm{m}^{-3} \mathrm{~K}^{-1}$ (Table 4).

\section{Waldhambach (Germany)}

The Waldhambach sandstones contain quartz (42-73 wt\%), K-feldspar (6-8 wt\%), albite (7-13 wt\%), illite/smectite (20-35 wt\%), and chlorite (2-10 wt\%) with accessory muscovite/illite (4 wt\%) in one sample (Table 1). Overall, the microstructure of the sandstone reflects a distinct lack of inter-granular pore space and is instead dominated by fractures (Fig. 4c). As with the granites and sandstones from Saint Pierre Bois, there is significant porosity associated with the dissolution of albite. The hydrothermally altered andesite contains quartz (16 wt\%), K-feldspar (20 wt\%), albite (30 wt\%), and chlorite (30 wt\%), and accessory hematite (4 wt\%). The rocks of the upper unit-the orange- to red-coloured sandstones-are similar to Permo-Triassic sandstones (including the Buntsandstein) that are ubiquitous to the region (see Heap et al. (2017); Vernoux et al. (1995) for the material characterisation of these rocks).

The connected porosity of the sandstones is between $0.04<\phi_{\mathrm{c}}<0.15$; the isolated porosity does not exceed 0.02 . While the hydrothermally altered andesite does not have any connected porosity, it has a total porosity of between 0.01 and 0.02 . P-wave velocity is greatest in the hydrothermally altered andesites $\left(4.85<V_{\mathrm{p}}<5.09 \mathrm{~km} \mathrm{~s}^{-1}\right)$ and lowest in the sandstones $\left(3.25<V_{\mathrm{p}}<4.00 \mathrm{~km} \mathrm{~s}^{-1}\right)$. The $\mathrm{P}$-wave velocity of the sandstones does not change significantly with porosity (Fig. 6). The permeability of the sandstones is between $7.37 \times 10^{-19}<k<2.06 \times 10^{-14} \mathrm{~m}^{2}$; the permeability of the andesites is $<10^{-19} \mathrm{~m}^{2}$. Overall, the permeability of the sandstones varies by more than four orders of magnitude over the entire porosity range (Fig. 6). Both permeability and P-wave velocity are lowest in the sandstones when the samples are cored perpendicular to the bedding plane. The UCS of the sandstones is between 47 and $80 \mathrm{MPa}$; elastic modulus $(E)$ is between 8 and $12 \mathrm{GPa}$. The hydrothermally altered andesite has a UCS of $269 \mathrm{MPa}$ and an elastic modulus $(E)$ of $34 \mathrm{GPa}$.

The thermal conductivity of the sandstones is between $2.21<\kappa<2.44 \mathrm{~W} \mathrm{~m}^{-1} \mathrm{~K}^{-1}$, thermal diffusivity ranges between $1.03<\alpha<1.41 \mathrm{~mm}^{2} \mathrm{~s}^{-1}$, and specific heat capacity is between $1.70<C_{\mathrm{p}}<2.16 \mathrm{MJ} \mathrm{m}^{-3} \mathrm{~K}^{-1}$ (Table 4). None of the thermal properties of the sandstones are correlated with porosity or mineralogical component. The thermal conductivity of the hydrothermally altered andesite is $2.75 \mathrm{~W} \mathrm{~m}^{-1} \mathrm{~K}^{-1}$, thermal diffusivity is $1.44 \mathrm{~mm}^{2} \mathrm{~s}^{-1}$, and specific heat capacity is $1.93 \mathrm{MJ} \mathrm{m}^{-3} \mathrm{~K}^{-1}$ (Table 4).

\section{Discussion}

Using the reservoir model of Soultz-sous-Forêts as a guide, we now discuss the rocks in this study as belonging to either the Paleozoic crystalline basement (i.e. granites and metagranites) or the Permo-Triassic sedimentary cover (i.e. sandstones and breccia); rocks that are observed at the Paleozoic-Permo-Triassic transition but that do not belong to either category (i.e. volcanic rocks or dolomites) are referred to broadly as other lithologies. 


\section{Thermal conductivity and seismic velocity}

There are notable correlations between thermal conductivity and the porosity, permeability, and P-wave velocity of the sedimentary rocks (Fig. 7). Of the basement rocks, the metagranites have a lower thermal conductivity than the granites $\left(2.93-2.95 \mathrm{~W} \mathrm{~m}^{-1} \mathrm{~K}^{-1}\right.$ as opposed to $3.17-3.44 \mathrm{~W} \mathrm{~m}^{-1} \mathrm{~K}^{-1}$ ) (Fig. 7a). While these rocks have similar and low porosity, their thermal conductivity is correlated with composition; the metagranites (TPG1 and TPG2) contain more albite and less quartz than the granites (WAG1, WAG2, and WAG3). The values of thermal conductivity of the granites from Saint Pierre Bois are consistent with those found for granites from the EPS-1 borehole, whose values range between 2.3 and $3.9 \mathrm{~W} \mathrm{~m}^{-1} \mathrm{~K}^{-1}$ for porosity values between 0.00 and 0.10 (Surma and Géraud 2003; Géraud et al. 2010) but remain at the high end of the range found from rocks from GPK-1 (1.97 and $2.91 \mathrm{~W} \mathrm{~m}^{-1} \mathrm{~K}^{-1}$, Rummel (1992)). Critically, thermal conductivity of granites from EPS-1 was observed to vary by more than $1 \mathrm{~W} \mathrm{~m}^{-1} \mathrm{~K}^{-1}$ in samples with the same porosity; this variability can be attributed, in part, to the influence of alteration to the granite, including hydrothermal alteration and the cementation of fracture networks (Surma and Géraud 2003).

Overall, the thermal conductivity of the sedimentary rocks in this study decreases with increasing total porosity from 1.54 to $3.66 \mathrm{~W} \mathrm{~m}^{-1} \mathrm{~K}^{-1}$ (Fig. 7a). We note that the sandstones from Waldhambach and breccia from Albersweiler have low thermal conductivities $\left(2.21-2.44 \mathrm{~W} \mathrm{~m}^{-1} \mathrm{~K}^{-1}\right)$ relative to their total porosity when compared to the sandstones from Saint Pierre Bois $\left(2.94-3.66 \mathrm{~W} \mathrm{~m}^{-1} \mathrm{~K}^{-1}\right)$. The thermal conductivity of these sandstones correlates with K-feldspar content; the Waldhambach sandstones and Albersweiler breccia contain significantly less K-feldspar (6-11 wt\%) than the Saint Pierre Bois sandstones (15-24 wt\%), though we note that this correlation may be tenuous owing to the relatively few samples $(n=3)$ of Waldhambach sandstones and Albersweiler breccia for which we have compositional data. The thermal conductivities of the sedimentary rocks from all sites are consistent with those measured for the Permo-Triassic sedimentary sequence from the EPS- 1 borehole $\left(2.08<\kappa<5.95 \mathrm{~W} \mathrm{~m}^{-1} \mathrm{~K}^{-1}\right.$; Haffen et al. (2013); Esteban et al. (2015); Haffen et al. (2017)). While thermal conductivity scans of individual cores of Buntsandstein sandstone suggest that thermal conductivity is relatively homogeneous over the decimetre-scale (Haffen et al. 2017), the range of values measured by Esteban et al. (2015) and Haffen et al. (2013) demonstrates the vast variability of this property over even a short depth interval $(400 \mathrm{~m})$ for rocks from the same sedimentary formation. In the present study we have sampled rocks from the PermoTriassic sedimentary sequences at four different locations within the Upper Rhine Graben; the variability of the thermal conductivity of these rocks also speaks to the large heterogeneity in thermal properties across large lateral distances. In addition to our observations of a correlation between thermal conductivity and the total porosity and composition of the rocks, we also observe that the thermal conductivity of all samples is inversely correlated with increasing permeability (Fig. 7b). This relationship may suggest a link between the geometry and connectivity of the rock void space and thermal properties, but such a link requires further experimental investigation of a larger dataset to ascertain the robustness of this trend.

The thermal conductivity of the sedimentary rocks is positively correlated with P-wave velocity (Fig. 7c); this observation is likely related to the increase in both thermal 

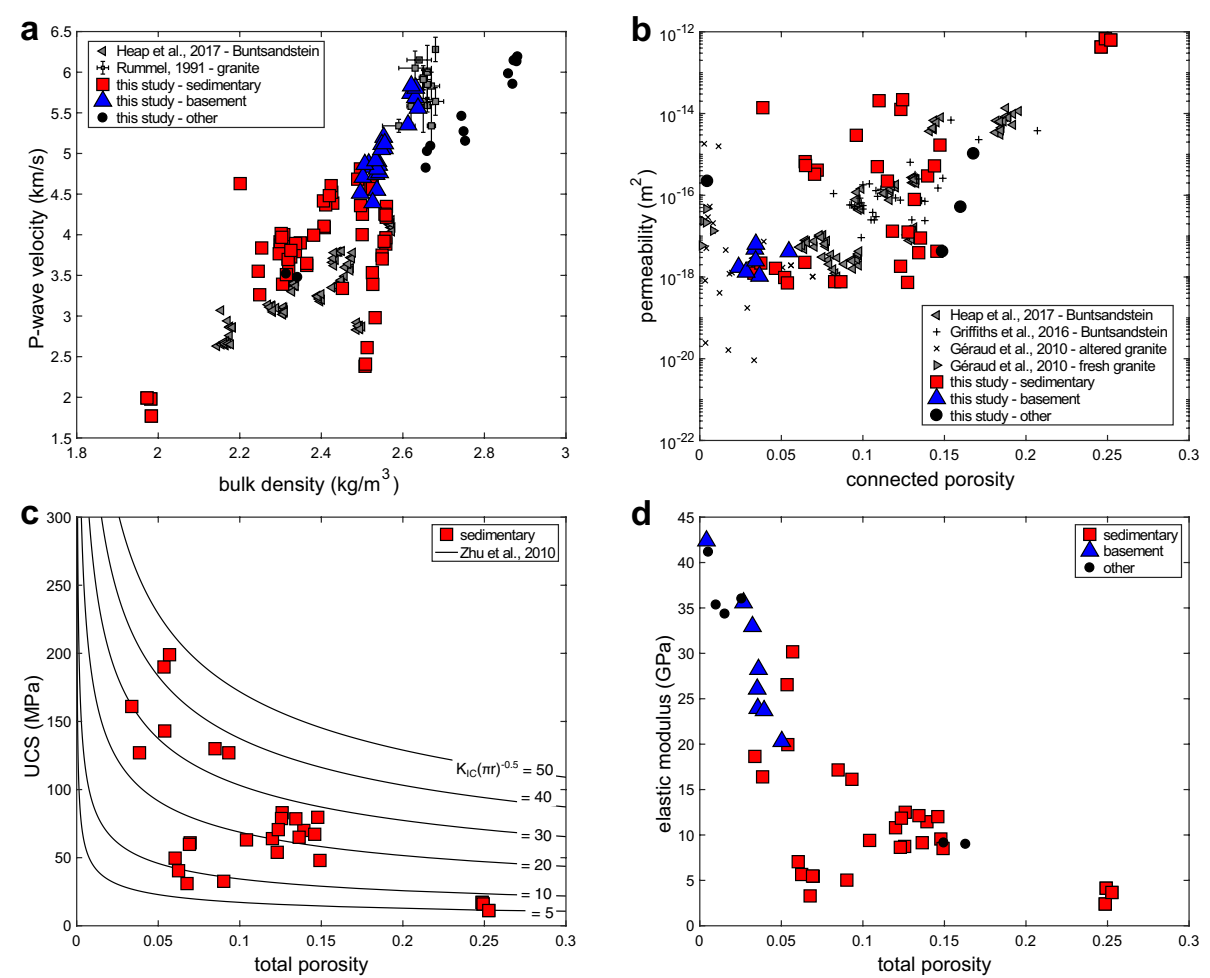

Fig. 8 a P-wave velocity as a function of bulk density. Grey triangles are data for Permo-Triassic sandstones from the EPS-1 exploratory borehole at Soultz-sous-Forêts, France (Heap et al. 2017); Grey squares are data for granites from the GPK-1 borehole at Soultz-sous-Forêts, France (Rummel 1992). Each square is the average value for a given depth and the error bars give the standard deviation. $\mathbf{b}$ Permeability as a function of connected porosity. We compare the data gathered in this study with data for the Permo-Triassic sandstones (Griffiths et al. 2016; Heap et al. 2017) and granites (Géraud et al. 2010) from the EPS-1 exploratory borehole at Soultz-sous-Forêts, France. c Uniaxial compressive strength of the sedimentary rocks investigated in the present study. Black curves - the analytical approximation of the pore-emanating crack model, as derived by Zhu et al. (2010). d Elastic modulus of the rocks investigated in the present study. The rocks from this study are categorised as either being sedimentary (red squares), from the crystalline basement (blue triangles), or as being other lithologies (black circles); see Table 2

conductivity and P-wave velocity associated with a decrease in rock porosity (Mielke et al. 2017). By contrast, the basement granites and metagranites show a decrease in thermal conductivity with increasing P-wave velocity, which may be related to a systematic decrease in quartz content. While quartz has a high thermal conductivity, its low density results in low compressional elastic wave velocities (Mielke et al. 2017). Indeed, P-wave velocity shows a strong correlation with bulk density (Fig. 8a; e.g. Reyer and Philipp (2014); Adelinet et al. (2010); Mielke et al. (2017)). In this study, the sedimentary rocks have, for the most part, lower density and P-wave velocity than the basement rocks, though there is significant variability in the P-wave velocity of the sedimentary rocks (Fig. 8a). With the exception of the hydrothermally altered Permian volcanic rocks (TPV), the other lithologies (including dolomite-WPD-and the metabasitesTPDG and TAB) are the densest of all the rocks owing to both their compositions and their low porosities. The range of P-wave velocity of the sedimentary rocks varies by as much as $2 \mathrm{~km} \mathrm{~s}^{-1}$ for any given density, but these values remain comparable to values of P-wave velocity determined on the Permo-Triassic sandstone sequences from EPS-1 
[2.0-5.5 $\mathrm{km} \mathrm{s}^{-1}$; Heap et al. (2017); Esteban et al. (2015)]. Similarly, P-wave velocities of the densest basement rocks in this study are consistent with average values of granite P-wave velocity from the GPK-1 borehole at Soultz-sous-Forêts (Rummel 1992) (Fig. 8a).

\section{Permeability}

Overall, the permeability of the rocks of the Paleozoic-Permo-Triassic transition in the Upper Rhine Graben increases with increasing connected porosity (Fig. 9b), as observed in sandstones and other granular materials (Bourbié and Zinszner 1985; Wadsworth et al. 2016). Of these, the sedimentary rocks have the highest permeability, which varies by over four orders of magnitude for any given porosity. The sedimentary rocks (WPS) from Raon l'Etape have the highest connected porosity and permeability owing to their poor cementation (Figs. 4a and 5a). Compared to studies of the permeability of the Permo-Triassic sandstone sequences collected from the EPS-1 borehole near Soultzsous-Forêts (Griffiths et al. 2016; Heap et al. 2017; Kushnir et al. 2018), the scattering of the permeability data for the sedimentary rocks studied here is large. This is an expression of the vast difference in cementation observed in the analogous quarry rocks from several different locations. Whereas the permeability of the Permo-Triassic sandstones sampled from EPS-1 show some variability (Heap et al. 2017), the samples in this study were chosen to represent the variability in lithological textures present near the sedimentary to crystalline transition at these outcrop locations and, thus, include variably cemented sandstones and breccia.

The basement rocks-granites and metagranites-have low connected porosity $(<0.05)$ and permeability $\left(<10^{-19}\right.$ to $7 \times 10^{-18} \mathrm{~m}^{2}$; Fig. $\left.8 \mathrm{~b}\right)$. Despite this, the granitic samples are more than two orders of magnitude more permeable than the metagranites (Table 3). The granite microstructure shows evidence of pervasive plagioclase dissolution. Evidence of plagioclase dissolution (Figs. $4 \mathrm{~d}$ and $5 \mathrm{~d}$ ) far from fractures is rife in the Upper Rhine Graben and the impregnation of these features with organic material speaks to the circulation of hydrothermal fluids outside of fracture zones (Ledesert et al. 2010; Sardini et al. 1997). These alteration processes can have a profound effect on rock matrix permeability. For example, fresh, intact granite from the EPS-1 borehole at the geothermal site near Soultz-sous-Forêts (France) has low porosity and permeability that does not vary by more than an order of magnitude (Géraud et al. 2010; Rummel 1992) (Fig. 8b). By contrast, granites characterised as altered (e.g. containing hematite, illite-hematite, or chlorite-hematite alteration) vary significantly in porosity (from 0.00 to 0.10 ) and permeability (over five orders of magnitude) (Géraud et al. 2010); these values are more comparable to the sedimentary sequences in this study. In some cases, where samples contain a pre-existing structural feature that may act as a conduit for flow (e.g. in-filled fracture; e.g. Figs. $4 \mathrm{~d}$ and $5 \mathrm{~d}$ ), the permeability of the rock is significantly increased with respect to other samples from the same block. Indeed, the presence of fractures-even partially in-filled fractures-can significantly increase the permeability of a given lithology without an accompanying significant increase in connected porosity (Kushnir et al. 2018; Hofmann et al. 2016; Nara et al. 2011; Wang et al. 2016; PérezFlores et al. 2017; Heap and Kennedy 2016; Lamur et al. 2017). 


\section{Uniaxial compressive strength and elastic moduli}

The uniaxial compressive strength of the rocks investigated in this study decreases with increasing total porosity (Fig. 8c), as has been previously observed by many studies (Chang et al. 2006; Baud et al. 2014; Diamantis et al. 2014; Reyer and Philipp 2014; Palchik 1999; Lama and Vutukuri 1978; Zhu et al. 2011, 2016). The UCS of the granites investigated in the present study (Table 4) are consistent with the UCS of unaltered granites from the GPK-1 and EPS-1 boreholes near Soultz-sous-Forêts (between 100 and 434 MPa; Valley and Evans (2006); Villeneuve et al. (2018)). As with the UCS, the elastic modulus of the transition zone rocks studied here is strongly correlated to total porosity, with the lowest porosity rocks having elastic moduli almost 10 times greater than the highest porosity rocks (Fig. 8d). The static elastic modulus of granites sampled from the GPK-1 and EPS-1 boreholes ranges between 26 and 75 GPa (Schäfer 1990; Rummel et al. 1989; Valley and Evans 2006; Villeneuve et al. 2018), which is appreciably higher than the granites from Saint Pierre Bois $(20<E<36 \mathrm{GPa})$. Overall, the sedimentary rocks (i.e. sandstones and breccia) investigated in this study have both lower UCS and elastic moduli than the crystalline basement rocks (granites and metagranites); similarly, the basement rocks tend to have lower UCS and elastic moduli than the other lithologies (including the dolomite and unaltered volcanic rocks) studied here.

Micromechanical modelling can be used to estimate the uniaxial compressive strength of rocks with different dominant microstructures, including cracks and pores (Ashby and Sammis 1990; Sammis and Ashby 1986). For example, Zhu et al. (2010) arrive at an analytical approximation for the UCS of porous rocks using the pore-emanated crack model of Sammis and Ashby (1986):

$$
\sigma_{\mathrm{UCS}}=\frac{1.325}{\phi^{0.414}} \frac{K_{\mathrm{IC}}}{\sqrt{\pi r}}
$$

where $\sigma_{\mathrm{UCS}}$ is the uniaxial compressive strength, $K_{\mathrm{IC}}$ is the fracture toughness, and $r$ is the radius of the pores in the material. The pore-emanated crack model of Sammis and Ashby (1986) describes a two-dimensional elastic medium populated by circular pores of uniform radius $r$. As the applied stress increases, cracks emanate (parallel to the direction of the applied stress) from the circular pores when the stress at the tip of a small crack on the pore surface reaches the critical value $K_{\mathrm{IC}}$. These pore-emanating microcracks grow and coalesce with increasing stress and, eventually, $\sigma_{U C S}$ is reached and the material fails macroscopically.

Alternatively, the strength of low-porosity rocks in which the porosity is fracturedominated-like the basement rocks of the current study-can be estimated using the 2D sliding wing crack model (Ashby and Sammis 1990). This model describes a twodimensional elastic medium populated by microcracks orientated at $45^{\circ}$ to the major principal stress. As the applied stress increases, wing cracks emanate from the tips of these microcracks and are oriented parallel to the direction of the applied stress. The model requires detailed knowledge of the friction coefficient of the microcracks $(\mu)$, the crack half-length $(c)$, the initial damage parameter $\left(D_{0}\right)$, and $K_{\text {IC }}$ (Griffiths et al. 2017a; Ashby and Sammis 1990).

Because the majority of the samples deformed in this study are sedimentary rocks with prominent pore space (Table 3), and that we would require additional experiments to 
constrain the $\mu$ and $D_{0}$ parameters in Ashby and Sammis' (1990) wing crack model, we have chosen to focus only on the application of the pore-emanating crack model to the sandstones and breccia in the present study. Furthermore, since the mineralogy of our rocks is varied (Table 1), we do not assign a specific $\mathrm{K}_{\mathrm{IC}}$ to the rocks but instead compare the measured UCS values to solutions of Eq. 4 as a function of $K_{\mathrm{IC}}(\pi r)^{-1 / 2}$, where $5<K_{\mathrm{IC}}(\pi r)^{-1 / 2}<50$ (Fig. 8c). We find that although the UCS decreases with increasing total porosity, as a whole, these data are not well described by Eq. 4 (Fig. 8c). While the sandstones from Raon l'Etape have distinct pores with radii on the order of $125 \mu \mathrm{m}$ (Fig. 5a), the pore space in the sandstones from Waldhambach (Fig. 4c) and from Saint Pierre Bois (Fig. 5e) manifests as microporosity restricted to the dissolved carcasses of feldspars; these partially dissolved feldspars are between 250 and $1000 \mu \mathrm{m}$ in length and are variably dissolved. Further, we note that several of the rocks contain pre-existing fractures (e.g. Fig. 4c, g), which are not considered in the micromechanical model of Sammis and Ashby (1986). Indeed, the pore-emanated crack model is appropriate for materials that contain a homogeneous distribution of equant pores, an assumption that is not satisfied by the sedimentary samples studied herein (Figs. 4 and 5). The poor fit between our data and the micromechanical model, which has been shown previously to accurately capture the mechanical behaviour of porous materials (Baud et al. 2014), is a testament to the variability in the microstructural attributes (e.g. pore size and shape (Přikryl 2001; Bubeck et al. 2017; Griffiths et al. 2017b), the presence of pre-existing microcracks (Kranz 1983), the presence of foliation or laminations (Baud et al. 2005; Rawling et al. 2002)) of our samples. This microstructural variability is highlighted by the large range in UCS values of the sedimentary rocks, where UCS can vary up to a factor of 4 for a given porosity (Fig. 8c).

\section{Implications for geothermal exploration}

The overall variability in lithology and petrophysical properties of the materials at the Paleozoic-Permo-Triassic interface in the Upper Rhine Graben highlights the need for comprehensive mapping of the transition zone throughout the region using geophysical techniques. For example, while the Paleozoic-Permo-Triassic transition at Soultzsous-Forêts and Rittershoffen is characterised by a change from sandstone to porphyritic granite with increasing depth (Aichholzer et al. 2016), this same transition is denoted by granite overlain by sandstones and volcanic sequences at Waldhambach. Similarly, at Albersweiler the basement metagranites are overlain, in part, by volcanic sequences. Further, the stratigraphy at Soultz-sous-Forêts and Rittershoffen, which are separated by a distance of $6.5 \mathrm{~km}$, are characterized by the same lithological units (Aichholzer et al. 2016). However, the quarries from which the rocks of the present study were procured are between 27 and $96 \mathrm{~km}$ from Soultz-sous-Forêts; at these distances, it is clear that there is considerable lithological variability at the Paleozoic-Permo-Triassic transition, highlighting the need for site-specific characterisation of this boundary.

The physical property data presented herein are intended to help inform modelling of these geothermal systems both locally and regionally. For example, the thermal properties, density, and elastic moduli can be used to better constrain regional convection and conduction models (e.g. Graf and Therrien (2009)) as well as thermomechanical models of the regional structure of the Upper Rhine Graben (e.g. Schwarz and Henk (2005)). 
However, it is important to note that the data presented here were not gathered under in situ reservoir conditions. The application of lithostatic pressure, in particular, can have a profound effect on the porosity and permeability of rocks. For example, as confining pressure is increased, micro- and macro-fractures begin to close, reducing porosity and permeability (e.g. Nara et al. (2011)). Further, though mineralogy, clay content, grain size, and fabric type may be comparable between outcrop analogues and reservoir rocks in the Upper Rhine Graben, compaction within the reservoir can lead to drastically different values of porosity and other physical properties, while the presence of hydrothermal brines may alter rock cementation (Bauer et al. 2017). Thus, caution should be used when incorporating the present data into reservoir modelling.

Sustained regional convection in the Upper Rhine Graben requires elevated permeability not only in the crystalline basement but also in the overlying Permo-Triassic sediments (Magnenet et al. 2014; Pribnow and Schellschmidt 2000; Guillou-Frottier et al. 2013; Lundgren et al. 2004; Graf and Therrien 2009). The rock matrix of the PermoTriassic sandstone overlying the Soultz-sous-Forêts geothermal reservoir is significantly more permeable than the granite matrix (Griffiths et al. 2016; Heap et al. 2017); however, despite some individual facies having relatively high matrix permeability values (Heap et al. 2017) and the fact that fluid flow may be facilitated parallel to bedding (Heap et al. 2017; Haffen et al. 2013), the Permo-Triassic sandstones as a whole do not have matrix permeability values sufficiently large to sustain regional hydrothermal convection (Graf and Therrien 2009; Magnenet et al. 2014; Kushnir et al. 2018). Instead, the permeability of this system is dependent on reservoir-scale fractures that permit persistent fluid flow over time (Graf and Therrien 2009; Genter et al. 1997; Dezayes et al. 2010; Vidal et al. 2015). Indeed, rock units with particularly low matrix permeability (e.g. metabasitesFig. 2a, b; samples TPDG and TAB in this study), not seen at Soultz-sous-Forêts or Rittershoffen, may hamper hydrothermal circulation locally. As a result, the ease of fracture creation and propagation in these rocks can profoundly influence the potential for efficient regional fluid circulation. However, the high strength of these materials (Table 4) is a further impediment to fracture development and thus the permeability of these rocks is likely to remain low over time. The contrast in stiffness of superposed rock units may strongly influence the ease with which fractures are able to propagate across lithological boundaries (Gudmundsson and Brenner 2001). For instance, dykes, mineral veins, and joints can become arrested at contacts in mechanically layered rocks (Gudmundsson and Brenner 2001; Gillespie et al. 2001), including at sedimentary bedding contacts (Baer 1991). Local stress conditions, however, can change which lithological layers arrest propagating fractures. For example, in systems under layer-parallel compression, stiff rock layers act as stress barriers against which fractures propagating through soft layers arrest; in tension, fractures propagate easily through stiff layers but arrest at interfaces with soft layers (Philipp et al. 2007; Gudmundsson and Brenner 2001). The granites, metagranites, dolomites, and volcanic rocks in the present study are stiffer than the sedimentary rocks (Fig. 8d). This may introduce appreciable mechanical contrasts at the lithological interfaces between the crystalline basement and overlying sedimentary sequences, resulting in disparate fracture populations between units. For example, in systems resembling Saint Pierre Bois (Fig. 2e), the interbedding of unlithified clays (less stiff) and sandstones (more stiff) may result in the compartmentalisation of fracture 
populations to either the clay or the sandstone horizons, depending on the local stress state. Ultimately, if this process is operative at depth, this may restrict fluid circulation to isolated horizons and perturb regional fluid convection. However, we emphasise that in this study we are unable to ascertain if the large-scale joints we observe in the field terminate at lithological contacts (Fig. 2d) because of mechanical contrasts or because the overlying units were deposited after joint creation. Nevertheless, we highlight that several of the lithologies studied here are not observed at the existing geothermal centres at Soultz-sous-Forêts and Rittershoffen and that the presence of the strongest of these materials may impede the economic viability of geothermal prospecting elsewhere in the Upper Rhine Graben.

\section{Conclusions}

Geothermal energy exploitation in the Upper Rhine Graben has targeted both the crystalline Paleozoic basement (e.g. at the EGS site near Soultz-sous-Forêts, France) and the transition between the crystalline basement and the overlying Permo-Triassic sandstones (e.g. near Rittershoffen, France). Exploiting geothermal resources at the Paleozoic-Permo-Triassic transition can significantly reduce the economic commitment necessary to instigate energy generation since injection and production wells can be drilled to more shallow depths than at Soultz-sous-Forêts. However, these more shallow depths (e.g. $2.5 \mathrm{~km}$ at Rittershoffen) still incur large drilling costs and pragmatic approaches to geothermal exploration in the region can help to curb these costs. Understanding the petrophysical variability of the rocks that straddle the PaleozoicPermo-Triassic transition in the Upper Rhine Graben can be used to inform geophysical exploration and regional convection and thermomechanical modelling in the area. While the sedimentary (i.e. sandstones and breccia) and granite basement rocks investigated here have porosity, permeability, P-wave velocity, and thermal properties consistent with rocks sampled from exploration and production wells at Soultz-sous-Forêts, the other lithologies present at the transition (i.e. metagranites, dolomites, and volcanic rocks) have conspicuously low permeability. Further, the contrast in rock strength and stiffness between these materials may hamper fracture propagation across lithological boundaries leading to the compartmentalisation of fracture zones. Locally, this may render fracture-assisted fluid flow untenable in these rocks and result in the curtailing of hydrothermal convection in these areas. The considerable lithological variability at the Paleozoic-Permo-Triassic transition in the Upper Rhine Graben highlights the need for site-specific characterisation to assess the viability of future geothermal resources in the area.

\section{Authors' contributions}

ARLK collected the samples from Saint Pierre Bois; performed the physical property measurements and data analysis; and wrote the manuscript, with contributions from all authors. MJH and PB collected the samples from Albersweiler, Walhambach, Saint Pierre Bois, and Raon I'Etape. HAG performed the XRPD measurements and analysis. TR contributed to the data analysis. PD led the 2016 field excursions to the Upper Rhine Graben quarries. CD and CL contributed to the fieldwork. All authors read and approved the final manuscript.

\footnotetext{
Author details

1 Géophysique Expérimentale, Institut de Physique du Globe de Strasbourg (UMR 7516, CNRS, Université de Strasbourg/ EOST), Strasbourg, France. ${ }^{2}$ Lehrstuhl für Ingenieurgeologie, Technische Universität München, Arcsstr. 21, 80333 Munich, Germany. ${ }^{3}$ Geothermal Department, BRGM, 3, Avenue C.-Guillemin, BP 36009, 45060 Orléans Cedex 2, France. ${ }^{4}$ Dynamique Globale, Institut de Physique du Globe de Strasbourg (UMR 7516, CNRS, Université de Strasbourg/EOST), Strasbourg, France.
} 


\section{Acknowledgements}

The authors thank the managers of the quarries and their associates for authorization to access the outcrops and site facilities: Jérémie de Bonneval of Leonhart for access to the Saint Pierre Bois quarry; Willi Kuhn of Gebrucher Kuhn for access to the Waldhambach quarry; Thierry Wojnowsdi of Colas Est for access to the Raon l'Etape quarry; and Christine Schultes of Basalt-Actien-Gesellschaft for access to the Albersweiler quarry. We additionally thank Bertrand Renaudié, Gilles Morvan, Luke Griffiths, and Olivier Lengliné. We thank two anonymous reviewers for their constructive comments.

\section{Competing interests}

The authors declare that they have no competing interests.

\section{Availability of data and materials}

All data are available in Tables 1 through 4.

\section{Funding}

This research was funded by the Agence Nationale de la Recherche (ANR) Grant CANTARE (ANR-15-CE06-0014-01); the LABEX Grant ANR-11-LABX-0050_G-EAU-THERMIE-PROFONDE; and by state funding managed by the ANR as part of the "Investissements d'avenir" program.

\section{Publisher's Note}

Springer Nature remains neutral with regard to jurisdictional claims in published maps and institutional affiliations.

Received: 22 May 2018 Accepted: 16 August 2018

Published online: 23 August 2018

\section{References}

Adelinet M, Fortin J, Guéguen Y, Schubnel A, Geoffroy L. Frequency and fluid effects on elastic properties of basalt: experimental investigations. Geophys Res Lett. 2010. https://doi.org/10.1029/2009GL041660.

Aichholzer C, Duringer P, Orciani S, Genter A. New stratigraphic interpretation of the Soultz-sous-Forêts 30-year-old geothermal wells calibrated on the recent one from Rittershoffen (Upper Rhine Graben, France). Geotherm Energy. 2016. https://doi.org/10.1186/s40517-016-0055-7.

Antics M, Sanner B Status of Geothermal Energy Use and Resources in Europe. In: Proceedings of the European Geothermal Congress, Unterhaching, Germany, 30 May-1 June 2007. p 8.

Ashby MF, Sammis CG. The damage mechanics of brittle solids in compression. Pure Appl Geophys. 1990;133(3):489-521. https://doi.org/10.1007/bf00878002.

Baer G. Mechanisms of Dike Propagation in Layered Rocks and in Massive, Porous Sedimentary-Rocks. J Geophys Res. 1991;96:11911-29.

Baria R, Baumgärtner J, Gérard A, Jung R, Garnish J. European HDR research programme at Soultz-sous-Forêts (France) 1987-1996. Geothermics. 1999;28(4-5):655-69.

Baud P, Louis L, David C, Rawling GC, Wong TF. Effects of bedding and foliation on mechanical anisotropy, damage evolution and failure mode. Geological Society, London, Special Publications. 2005;245(1):223-49.

Baud P, Wong TF, Zhu W. Effects of porosity and crack density on the compressive strength of rocks. Int J Rock Mech Min Sci. 2014;67:202-11. https://doi.org/10.1016/j.jirmms.2013.08.031.

Bauer JF, Krumbholz M, Meier S, Tanner DC. Predictability of properties of a fractured geothermal reservoir: the opportunities and limitations of an outcrop analogue study. Geotherm Energy. 2017. https://doi.org/10.1186/s4051 7-017-0081-0.

Baujard C, Genter A, Dalmais E, Maurer V, Hehn R, Rosillette R, Vidal J, Schmittbuhl J. Hydrothermal characterization of wells GRT-1 and GRT-2 in Rittershoffen, France: implications on the understanding of natural flow systems in the Rhine graben. Geothermics. 2017;65:255-68.

Baumgärtner J, Lerch C (2013) Geothermal 2.0: The Insheim Geothermal Power Plant. the second generation of geothermal power plants in the Upper Rhine Graben. In: Proceedings of Third European Geothermal Review

Bergmann J, Friedel P, Kleeberg R. BGMN — a new fundamental parameters based Rietveld program for laboratory $X$-ray sources, its use in quantitative analysis and structure investigations. CPD Newslett. 1998;20:5.

Bieniawski ZT, Franklin JA, Bernede MJ, Duffaut P, Rummel F, Horibe T, Broch E, Rodrigues E, van Heerden WL, Vogler UW, Hansagi I, Szlavin J, Brady BT, Deere DU, Hawkes I, Milovanovic D (2007) Suggested Methods for Determining the Uniaxial Compressive Strength and Deformability of Rock Materials. The Complete ISRM Suggested Methods for Rock Characterization, Testing and Monitoring: 1974-2006. Kozan Ofset Matbaacilik San. ve Tic. Sti., Ankara, Turkey.

Bourbié T, Zinszner B. Hydraulic and acoustic properties as a function of porosity in Fontainbleau sandstone. J Geophys Res. 1985;90(B13):1524-32. https://doi.org/10.1029/JB090iB13p11524.

Brace WF, Walsh JB, Frangos WT. Permeability of granite under high pressure. J Geophys Res. 1968;73:2225-36.

Bubeck A, Walker RJ, Healy D, Dobbs M, Holwell DA. Pore geometry as a control on rock strength. Earth Planet Sci Lett. 2017:457:38-48.

Chang C, Zoback MD, Khaksar A. Empirical relations between rock strength and physical properties in sedimentary rocks. J Petrol Sci Eng. 2006;51:223-37. https://doi.org/10.1016/j.petrol.2006.01.003.

Dezayes C, Genter A, Valley B. Structure of the low permeable naturally fractured geothermal reservoir at Soultz. CR Geosci. 2010;342(7-8):517-30. https://doi.org/10.1016/j.crte.2009.10.002.

Diamantis K, Gartzos E, Migiros G. Influence of petrographic characteristics on physico-mechanical properties of ultrabasic rocks from central Greece. Bull Eng Geol Environ. 2014;73(4):1273-92. https://doi.org/10.1007/s1006 4-014-0584-x. 
Dusseault MB. Geomechanical challenges in petroleum reservoir exploitation. KSCE J Civil Eng. 2011;15:669-78. Esteban L, Pimienta L, Sarout J, Delle Piane C, Haffen S, Géraud Y, Timms NE. Study cases of thermal conductivity prediction from P-wave velocity and porosity. Geothermics. 2015;53:255-69. https://doi.org/10.1016/j.geoth ermics.2014.06.003.

Farquharson JI, Heap MJ, Lavallee Y, Varley NR, Baud P. Evidence for the development of permeability anisotropy in lava domes and volcanic conduits. J Volcanol Geoth Res. 2016;323:163-85. https://doi.org/10.1016/j.jvolgeores 2016.05.007.

Farquharson J, Baud P, Heap MJ. Inelastic compaction and permeability evolution in volcanic rock. Solid Earth. 2017;8:561-81. https://doi.org/10.5194/se-8-561-2017.

Forchheimer P. Water movement through ground. Zeitschrift Des Vereines Deutscher Ingenieure. 1901;45:1736-41. Genter A, Castaing C, Dezayes C, Tenzer H, Traineau H, Villemin T. Comparative analysis of direct (core) and indirect (borehole imaging tools) collection of fracture data in the Hot Dry Rock Soultz reservoir (France). J Geophys Res. 1997;102(B7):15419-31. https://doi.org/10.1029/97jb00626.

Gérard A, Kappelmeyer O. The Soultz-sous-Forêts project. Geothermics. 1987;16(4):393-9.

Gérard A, Genter A, Kohl T, Lutz P, Rose P, Rummel F. The deep EGS (Enhanced Geothermal System) project at Soultz-sous-Forêts (Alsace, France). Geothermics. 2006;35(5-6):473-83. https://doi.org/10.1016/j.geothermic s.2006.12.001.

Géraud Y, Rosener M, Surma F, Place J, Le Garzic E, Diraison M. Physical properties of fault zones within a granite body: example of the Soultz-sous-Forets geothermal site. CR Geosci. 2010;342(7-8):566-74. https://doi.org/10.1016/j. crte.2010.02.002.

Gillespie PA, Walsh JJ, Watterson J, Bonson CG, Manzocchi T. Scaling relationships of joint and vein arrays from The Burren, Co., Clare, Ireland. J Struct Geol. 2001;23:183-201.

Graf T, Therrien R. Stable-unstable flow of geothermal fluids in fractured rock. Geofluids. 2009;9:138-52. https://doi.org/1 0.1111/j.1468-8123.2008.00233.x.

Griffiths L, Heap MJ, Wang F, Daval D, Gilg HA, Baud P, Schmittbuhl J, Genter A. Geothermal implications for fracture-filling hydrothermal precipitation. Geothermics. 2016;64:235-45. https://doi.org/10.1016/j.geothermics.2016.06.006.

Griffiths L, Heap MJ, Baud P, Schmittbuhl J. Quantification of microcrack characteristics and implications for stiffness and strength of granite. Int J Rock Mech Min Sci. 2017a;100:138-50. https://doi.org/10.1016/j.jirmms.2017.10.013.

Griffiths L, Heap MJ, Xu T, Chen CF, Baud P. The influence of pore geometry and orientation on the strength and stiffness of porous rock. J Struct Geol. 2017b;96:149-60.

Gudmundsson A, Brenner SL. How hydrofractures become arrested. Terra Nova. 2001;13(6):456-62. https://doi.org/10.10 46/j.1365-3121.2001.00380.x.

Guillou-Frottier L, Carre C, Bourgine B, Bouchot V, Genter A. Structure of hydrothermal convection in the Upper Rhine Graben as inferred from corrected temperature data and basin-scale numerical models. J Volcanol Geoth Res. 2013;256:29-49. https://doi.org/10.1016/j.jvolgeores.2013.02.008.

Gustafsson SE. Transient plane source techniques for thermal conductivity and thermal diffusivity measurements of solid materials. Rev Sci Instrum. 1991;62(3):797. https://doi.org/10.1063/1.1142087.

Haffen S, Géraud Y, Diraison M, Dezayes C. Determination of fluid-flow zones in a geothermal sandstone reservoir using thermal conductivity and temperature logs. Geothermics. 2013;46:32-41. https://doi.org/10.1016/j.geothermic s.2012.11.001.

Haffen S, Géraud Y, Rosener M, Diraison M. Thermal conductivity and porosity maps for different materials: a combined case study of granite and sandstone. Geothermics. 2017;66:143-50.

Heap MJ, Kennedy BM. Exploring the scale-dependent permeability of fractured andesite. Earth Planet Sci Lett. 2016:447:139-50. https://doi.org/10.1016/j.epsl.2016.05.004

Heap MJ, Baud P, Meredith P, Vinciguerra S, Reuschlé T. The permeability and elastic moduli of tuff from Campi Flegrei, Italy: implications for ground deformation modelling. Solid Earth. 2014;5:25-44. https://doi.org/10.5194/ se-5-25-2014.

Heap MJ, Kushnir ARL, Gilg HA, Wadsworth FB, Reuschlé T, Baud P. Microstructural and petrophysical properties of the Permo-Triassic sandstones (Buntsandstein) from the Soultz-sous-Forêts geothermal site (France). Geothermal Energy. 2017. https://doi.org/10.1186/s40517-017-0085-9.

Hettkamp T, Baumgärtner J, Teza D, Lerch C (2013) Experiences from 5 years operation in Landau. In: Proceedings of Third European Geothermal Review

Hofmann H, Bloecher G, Milsch H, Babadagli T, Zimmermann G. Transmissivity of aligned and displaced tensile fractures in granitic rocks during cyclic loading. Int J Rock Mech Min Sci. 2016;87:69-84. https://doi.org/10.1016/j.jirmm s.2016.05.011.

Housse BA (1984) Reconnaissance du potentiel géothermique du Buntsandstein à Strasbourg-Cronenbourg. Géothermie Actualités 1, vol Géothermie Actualités 1.

ISO22007-2 (2015) Determination of thermal conductivity and thermal diffusivity_-Part 2: Transient plane heat source (hot disk) method.

Kappelmeyer O, Gérard A, Schloemer W, Ferrandes R, Rummel F, Benderitter Y. European HDR project at Soultz-sousForêts: general presentation. Geotherm Sci Technol. 1991;2(4):263-89.

Khaksar A, Taylor PG, Kayes T, Salazar A, Rahman K. Rock strength from Core and logs: Where we stand and ways to go. Amsterdam: Paper presented at the SPE EUROPEC/EAGE; 2009.

Klinkenberg LJ. The permeability of porous media to liquids and gases. Drilling and production practice. New York: American Petroleum Institute; 1941. p. 200-13.

Kranz RL. Microcracks in rocks: a review. Tectonophysics. 1983:100(1-3):449-80.

Kushnir ARL, Heap MJ, Baud P. Assessing the role of fractures on the permeability of the Permo-Triassic sandstones at the Soultz-sous-Forêts (France) geothermal site. Geothermics. 2018;74:181-9. https://doi.org/10.1016/j.geothermic s.2018.03.009

Lama RD, Vutukuri VS. Handbook on mechanical properties of rocks-testing techniques and results, vol. II. Clausthal: Trans Tech Publications; 1978. 
Lamur A, Kendrick JE, Eggertsson GH, Wall RJ, Ashworth JD, Lavallée Y. The permeability of fractured rocks in pressurised volcanic and geothermal systems. Sci Rep. 2017;7:1-9. https://doi.org/10.1038/s41598-017-05460-4.

Laplaige P, Jaudin F, Desplan A, Demange J (2000) The French geothermal experience review and perspectives. In: Proceedings of the world geothermal congress, Kyushu-Tohoku, Japan, pp 283-295.

Ledesert B, Hebert R, Genter A, Bartier D, Clauer N, Grall C. Fractures, hydrothermal alterations and permeability in the Soultz Enhanced Geothermal System. CR Geosci. 2010;342(7-8):607-15. https://doi.org/10.1016/j.crte.2009.09.011.

Li S, George J, Purdy C. Pore-pressure and wellbore-stability prediction to increase drilling efficiency. J Petrol Technol. 2012;64:99-101.

Lund JW, Freeston DH, Boyd TL (2005) World-wide direct uses of geothermal energy 2005. In: Proceedings World Geothermal Congress 2005, Antalya, Turkey

Lundgren P, Casu F, Manzo M, Pepe A, Berardino P, Sansosti E, Lanari R. Gravity and magma induced spreading of Mount Etna volcano revealed by satellite radar interferometry. Geophys Res Lett. 2004;31:L04602. https://doi. org/10.1029/2003GL018736.

Magnenet V, Fond C, Genter A, Schmittbuhl J. Two-dimensional THM modelling of the large scale natural hydrothermal circulation at Soultz-sous-Forêts. Geotherm Energy. 2014. https://doi.org/10.1186/s40517-014-0017-x.

Mahler A, Magtengaard J (2005) Geothermal Development in Denmark, Country Update 2005. In: Proceedings, world geothermal congress 2005, Turkey

Menzel H, Seibt P, Kellner P (2000) Five years of experience in the operation of the Neustadt-Glewe geothermal project. In: Proceedings of the world geothermal congress, Kyushu-Tohoku, Japan, pp 3501-3504.

Mielke P, Bar K, Sass I. Determining the relationship of thermal conductivity and compressional wave velocity of common rock types as a basis for reservoir characterization. J Appl Geophys. 2017;140:135-44. https://doi.org/10.1016/j.jappg eo.2017.04.002.

Nara Y, Meredith PG, Yoneda T, Kaneko K. Influence of macro-fractures and micro-fractures on permeability and elastic wave velocities in basalt at elevated pressure. Tectonophysics. 2011;503(1-2):52-9. https://doi.org/10.1016/j.tecto .2010.09.027.

Okrusch M. Metamorphic Evolution. In: Dallmeyer RD, Franke W, Weber K, editors. Pre-Permian Geology of Central and Eastern Europe. IGCP-Project 233 (Terranes In The Circum-Atlantic Paleozoic Orogens). Berlin: Springer; 1995.

Palchik V. Influence of porosity and elastic modulus on uniaxial compressive strength in soft brittle porous sandstones. Rock Mech Rock Eng. 1999;32:303-9.

Paschen H, Oertel D, Grünwald R (2003) Möglichkeiten geothermischer Stromerzeugung in Deutschland. TAB Arbeitsbericht.

Pérez-Flores P, Wang G, Mitchell TM, Meredith PG, Nara Y, Sarkar V, Cembrano J. The effect of offset on fracture permeability of rocks from the Southern Andes Volcanic Zone, Chile. J Struct Geol. 2017. https://doi.org/10.1016/j. jsg.2017.09.015.

Philipp SL, Gudmundsson A, Oelrich ARI How structural geology can contribute to make geothermal projects successful. In: Proceedings of the European geothermal congress, Unterhaching, Germany, 30 may-1 June 2007.

Pribnow D, Schellschmidt R. Thermal tracking of upper crustal fluid flow in the Rhine Graben. Geophys Res Lett. 2000;27(13):1957-60. https://doi.org/10.1029/2000gl008494.

Prrikryl R. Some microstructural aspects of strength variation in rocks. Int J Rock Mech Min Sci. 2001;38(5):671-82.

Proehl TS (2002) Geomechanical uncertainties and exploratory drilling costs. Paper presented at the SPE/ISRM Rock Mechanics Conference, Irving

Rawling GC, Baud P, Wong TF. Dilatancy, brittle strength, and anisotropy of foliated rocks: experimental deformation and micromechanical modeling. J Geophys Res. 2002;107:B10.

Reyer D, Philipp SL. Empirical relations of rock properties of outcrop and core samples from the Northwest German Basin for geothermal drilling. Geotherm Energy Sci. 2014;2:21-7. https://doi.org/10.5194/gtes-2-21-2014.

Rummel F. Physical properties of the rock in the granitic section of borehole GPK1, Soultz-sous-Forêts. In: Bresee JC editor. Geothermal Energy in Europe: the soultz hot dry rock project. Switzerland: Gordon and Breach Science Publishers; 1992.

Rummel F, Kamp L, Schäfer T. Fracture mechanic properties of granite cores from GPK1. Yellow report 7. Bochum: RuhrUniversität; 1989.

Sammis CG, Ashby MF. The failure of brittle porous solids under compressive stress states. Acta Metall. 1986;34(3):511-26. https://doi.org/10.1016/0001-6160(86)90087-8.

Sardini P, Ledésert B, Touchard G. Quantification of microscopic porous networks by image analysis and measurements of permeability in the Soultz-sous-Forêts granite. In: Jamtveit B, Yardley BW, editors. Fluid Flow and Transport in Rocks. New York: Chapman and Hall; 1997. p. 171-89.

Schäfer T. Ultraschallunguntersuchungen an Granitbohrkerne der Bohrung Soultz-sous-Forêts bezüglich einer Abschätzung von in situ Spannungen anhand von Riessschliessungdrücken. Bochum: Ruhr-Universität; 1990.

Schwarz M, Henk A. Evolution and structure of the Upper Rhine Graben: insights from three-dimensional thermomechanical modelling. Int J Earth Sci. 2005;94:732-50. https://doi.org/10.1007/s00531-004-0451-2.

Surma F, Géraud Y. Porosity and thermal conductivity of the Soultz-sous-Forets granite. Pure Appl Geophys. 2003;160(56):1125-36. https://doi.org/10.1007/pl00012564.

Ungemach P, Antics M. The road ahead toward sustainable geothermal development in Europe. Trans Geotherm Resour Council. 2010;34(1):146-59.

Valley B, Evans KF Strength and elastic properties of the Soultz granite. In: EHDRA Scientific Conference, Soultz-sousForêts, France; 2006. pp 15-16.

Vernoux JF, Genter A, Razin P, Vinchon C. Geological and petrophysical parameters of a deep fractured sandstone formation as applied to geothermal exploitation, EPS-1 borehole, Soults-sous-Forêts, France. BRGM: BRGM Open File Rep; 1995.

Vidal J, Genter A, Schmittbuhl J. How do permeable fractures in the Triassic sediments of northern Alsace characterize the top of hydrothermal convective cells? Evidence from Soultz geothermal boreholes (France). Geotherm Energy. 2015. https://doi.org/10.1186/s40517-015-0026-4. 
Villeneuve MC, Heap MJ, Kushnir ARL, Qin T, Baud P, Zhou G, XU T. Estimating in situ rock mass strength and elastic modulus of granite from the Soultz-sous-Forêts geothermal reservoir (France). Geotherm Energy. 2018. https://doi. org/10.1186/s40517-018-0096-1.

Wadsworth FB, Vasseur J, Scheu B, Kendrick JE, Lavallée Y, Dingwell D. Universal scaling of fluid permeability during volcanic welding and sediment diagenesis. Geology. 2016;44(3):219-22.

Wang G, Mitchell TM, Meredith PG, Nara Y, Wu Z. Influence of gouge thickness and grain size on permeability of macrofractured basalt. J Geophys Res Solid Earth. 2016;121(12):8472-87. https://doi.org/10.1002/2016jb013363.

York P, Pritchard D, Dodson JK, Rosenberg S, Gala S, Utama B (2009) Eliminating non-productive time associated with drilling trouble zones. Paper presented at the Offshore Technology Conference 2009, Houston

Zeynali ME. Mechanical and physico-chemical aspects of well-bore stability during drilling operations. J Petrol Sci Eng. 2012:82-83:120-4.

Zhu W, Baud P, Wong T-F. Micromechanics of cataclastic pore collapse in limestone. J Geophys Res. 2010. https://doi. org/10.1029/2009JB006610.

Zhu W, Baud P, Vinciguerra S, Wong T-F. Micromechanics of brittle faulting and cataclastic flow in Alban Hills tuff. J Geophys Res. 2011;116:B06209. https://doi.org/10.1029/2010JB008046.

Zhu W, Baud P, Vinciguerra S, Wong TF. Micromechanics of brittle faulting and cataclastic flow in Mount Etna basalt. J Geophys Res. 2016;121(6):4268-89. https://doi.org/10.1002/2016jb012826.

\section{Submit your manuscript to a SpringerOpen ${ }^{\circ}$} journal and benefit from:

- Convenient online submission

Rigorous peer review

- Open access: articles freely available online

- High visibility within the field

Retaining the copyright to your article

Submit your next manuscript at $\boldsymbol{\Delta}$ springeropen.com 